\title{
Mehmed Zihni Efendi Örneğinde Sahîh-i Buhârî Baskılarının Tashihi
}

\author{
Revising the Publications of Sahīh al-Bukhārī in the Example of \\ Mehmed Zihni Efendi
}

\begin{abstract}
Ali ALBAYRAK ${ }^{*}$
Öz: İslâm dünyasında ilk olarak Hindistan'da basılan (1270/1853) Buhârînin (ö. 256/870) el-Câmi u's-sahîh adlı eserinin en bilinen ve kabul gören neşri Sultan Abdülhamid'in (ö. 1918) talimatıyla Ezherli âlimler tarafından Mısır'da gerçekleştirilmiştir (1313/1896). Hemen sonrasında Mehmed Zihni Efendi (ö. 1913) de Sahîh'in İstanbul'daki ilk neşrini yapmıştır. Bu neşirlerde Sahîh-i Buhârî yazmaları içerisinde meşhur olan Yûnînî nüshası kullanılmıştır. Bilindiği gibi Ali b. Muhammed el-Yûnînî (ö. 701/1302) kendi nüshasını ana metin olarak aktarırken elindeki diğer dört nüshanın farklarını metin üzerinde ve kenarlarda (hamiş) göstermiştir. Yûnînînin çok titiz bir şekilde tüm farklarını yansıttığı bu dört nüsha Asîlî (ö. 392/1002), Ebû Zer (ö. 434/1043), İbn Asâkir (ö. 571/1176) ve Semânîye (ö. 562/1167) aittir. İki neşirde de Yûnînî nüshası kullanılmasına rağmen aralarında bazı farklar vardır. Ezherli âlimler Yûnînî nüshasını ana metin ve kenardaki yoğun notlar şeklinde basarken, Mehmed Zihni Efendi ise günümüze daha yakın bir anlayışla sadece ana metni yansıtmıştır. Fakat ana metin açısından da aralarında farklar vardır. Çünkü Ezherli âlimler ana metni çok az bir tashihle aynen naklederken Zihni Efendi, Kastallânînin (ö. 923/1517) şerhindeki metni esas aldığından daha fazla tashih yapmıştır. Kastallânî șerhi de Yûnînî nüshasına göre yazıldığı halde ana metnin kimi yerlerde farklı olmasının sebebi, onun Sahîh-i Buhârî metnini belirtirken yapmış olduğu tercihlerdir. Çünkü o kimi zaman farklı nüshalardaki ifadeleri ana metin olarak öne çıarmıştır. Genelde İbn Hacer'in (ö. 852/1449) etkisiyle oluşan bu tercihler, Zihni Efendi’nin neşrinde ve İslâm dünyasında basılan ilk Buhârî şerhlerine eklenen Sahîh metninin kısmen farklı olmasındaki en önemli etkendir. Günümüz Sahîh-i Buhârî baskılarında ve Buhârî şerhlerinde ise Ezherli âlimlerin neşrindeki ana metin kullanılmaktadır.

Asîlî̀den bu yana yansıtılmaya çalışılan farklılığın temelinde Sahîh-i Buhârî nüshaları arasındaki farklar bulunduğundan makalede önce bu temel nüshalar kısaca tanıtılmıştır. Ardından bu nüshalardaki farklılığı konu edinen Ebû Ali el-Gassânî el-Ceyyânî (ö. 498/1105) ve Kadı İyâz’ın (ö. 544/1149) eserlerinden bahsedilmiş, nüshalar arasındaki farkları titizlikle gösteren sonraki çalışmalardan Radıyyüddin Hasan b. Muhammed es-Sagânî (ö. 651/1252) ve Yûnînînin nüshaları ile Ahmed es-Sehârenfûrînnin (ö. 1297/1880) haşiyesine dair bazı bilgiler verilmiştir. Tashihle ilgili özet bir bilgilendirmeden sonra mezkûr isimlerin Sahîh nüshalarındaki hataları belirtmelerine ve tashih işlemlerine örnekler sunulmuş, Yûnînî nüshasının en muteber kopyasını yazdığı kabul edilen Abdullah b. Sâlim el-Basrînin (ö. 1134/1722) tashihe yönelik notlarına da değinilmiştir. Daha sonra Ezherli âlimlerin Bulak neşrinde yaptığı tashihlerden tespit edilenler belirtilip Mehmed Zihni Efendi’nin tashihlerine geçilmiştir.
\end{abstract}

* Araştırmacı, binicimusavirlik@hotmail.com, Orcid No: 0000-0002-0319-597X 
Osmanlı’nın son dönemindeki iyi yetişmiş ve müktesebatı geniş âlimlerinden biri olan Zihni Efendi yenilikçi yönüyle ve güzel ahlakıyla tanınır. Gerek Arapça öğretiminde gerekse diğer eserlerinde ortaya çıkan bu yenilikçi yönü sayesinde Sahîh-i Buhârî̀nin İstanbul'daki ilk neşri ona nasip olmuştur. Matbaada uzun yıllar yapmış olduğu musahhihliğin getirdiği tashih tecrübesiyle "Zihni” mahlasını almasını sağlayan kıvrak zekâsının bir sonucu olarak bu neşir, günümüz baskılarında bulunmayan tashihler içerir. Zihni Efendi’nin söz konusu tashihlerinin ayrıntılı olarak incelendiği bu çalışma günümüz baskılarıyla mukayese etmek suretiyle onun başarısını ortaya koymayı ve böylelikle tashih çalışmalarının önemini vurgulamayı amaçlamaktadır. Bunun yanında onun eksik ve yanlış tashihlerini veya gözden kaçırdığı bariz yerleri de belirtmek suretiyle hadis külliyatındaki tashih işleminin kolay bir şey olmadığına ve tashih çalışmalarının devam etmesi gerektiğine dikkat çekmek istenilmiştir. Çünkü Sahîh-i Buhârî gibi temel bir eserin tashihi, devamlılık isteyen ve birikimli olması gereken bir süreçtir. Şüphesiz bunun kurumsal olması ve bütün temel eserleri kapsaması temennimizdir.

Anahtar Kelimeler: Hadis, Sahîh-i Buhârî baskıları, Yûnînî, tashih, Mehmed Zihni Efendi.

Abstract: The first publication of Bukhārīs al-Jāmi' al-sahīh in the Islamic world was in India in 1270/1853. However, the most famous and acknowledged edition of it was carried out by al-Azharī scholars in Egypt in 1313/1896 with the instruction of Sultan Abdul Hamid (d. 1918). Just after this publication, Mehmed Zihni Efendi (d. 1913) published Sahìh's first edition in Istanbul. In these editions, the famous Yūnīnì version of Sahìh was used in Istanbul. As is generally well-known by scholars of hadith, while putting his copy at the center of his transmission, Alī b. Muhammad al-Yūnīnī (d. 701/1302) demonstrated the differences of the other four versions of Sahi h in the text and in the footnotes of the text. The four copies are Asīlī (d. 392/1002), Abū Zar (d. 434/1043), Ibn Asākir (d. 571/1176), and Samānī (d. 562/1167). Despite the use of the Yūninnìs copy in the both the editions, there are some differences between them. While Azharī scholars have published the Yūnīnìs copy as main text and footnotes, Mehmed Zihni Efendi has published only the main text, which is close to the modern edition approach. However, there are differences between them in terms of the main text. While the Azhari scholars have published the main text with minor corrections, Mehmed Zihni Efendi, on the other hand, has taken Kastallānìs (d. 923/1517) commentary of al-Jāmi al-Sahīh into consideration and made major corrections in his copy. Though Kastallānī’s commentary is based on Yūnūnỉs copy, there are some differences between the main text and its commentary because of the preferences of Kastallānī. The main reason for the differences is that Kastallānī highlighted some of the expressions of the different copies as the main text. These preferences, which are usually influenced by Ibn Hajar (d. 852/1449), are the most important factor in the edition of Zihni Efendi's text and the Sahīh text added to the first Bukhārī commentaries published in the Islamic world. The main text of the Azhari scholars' edition is used in contemporary al-Sahīh al-Bukhärī prints and its commentaries.

Since there are differences among editions of al-Sahīh al-Bukhärī, this article introduces its main versions. After that, the article deals with Abū Alī al-Ghassānī al-Jayyānī (d. 498/1105), Qādī 'Iyād, Radī al-Dīn Hasan b. Muhammad al-Sagānī (d. 651/1252), and Ahmad al-Sahäranfūrìs works that mention the differences of these copies. After giving a summary of the corrections, the effort of the aforementioned scholars is evaluated by giving some samples of revisions. Moreover, in this article Abdullah b. Sālim al-Basrīss notes in his edition, which is the most acknowledged copy of Yūnīnīs version, are also evaluated. Finally some corrections of the Azharī scholars' Bulaq version are specified and Mehmed Zihni Efendi's revisions are deliberated upon. 
Zihni Efendi, one of the well-educated scholars of the late Ottoman period, is renowned for his innovative ideas and good morality. Due to his innovative ideas, which are reflected both in his Arabic and his scholarly works, the first publication of al-Sahì alBukhārī in Istanbul was successfully accomplished. As a result of his experience as a proofreader in the printing house for many years and his subtle understanding that earned him the title of "Zihni", his edition contains revisions that we don't have in today's editions. This study, in which the revisions of Zihni Efendi are examined in detail, aims to emphasize its success by comparing it with contemporary editions and thus emphasizes the importance of revision works. In addition, the emphasis will be on the difficulty of the process of revision in hadith manuals by pointing out the missing and incorrect revisions or some parts that he failed to notice. Hence it is understood that the revision of al-Sahīh al-Bukhārì requires continuation and accumulation of scholarly works. We hope that such works may be in the future be found in most institutions and be covered by all the main reference books.

Keywords: Hadīth, Publications of Sahīh al-Bukhārī, Yūnīnī, revision, Mehmed Zihni Efendi.

\section{GíRIŞ}

Sahîh-i Buhârî İslâm dünyasında ilk defa 1853 yılında Hindistan'da neşredilmiştir. İleride değineceğimiz bu neşirden sonra Sahîh birçok defa basılmıştır ki, bunların en meşhuru II. Abdülhamid'in (ö. 1918) emriyle Ezherli âlimler tarafından 1895'te Mısır'da gerçekleștirilen baskıdır. Bulak’taki bir matbaada basıldığı için "Bulak baskısı" ve Sultan II. Abdülhamid'in gönderdiği nüsha kullanıldığ i i̧in de "en-Nüshatü’s-Sultâniye" olarak bilinen bu neşirde, klasik dönemde Sahîh-i Buhârî̀yle ilgili en titiz çalışma kabul edilen Yûnînî nüshası kullanılmıştır.

Eserin İstanbul'daki ilk basımı ise 1897 senesinde son dönem Osmanlı müderrislerinden Mehmed Zihni Efendi (ö. 1913) tarafından yapılmıştır. İstanbul baskısında da Yûnînî nüshası kullanılmış fakat bu nüshada bulunan ve hamişlerle (kenarnot) gösterilen nüsha farkları yansıtılmamış, sadece nüshadaki ana metin nakledilmiştir. Mehmed Zihni’nin yapmış olduğu İstanbul baskısı Sahîh'in Yûnînî edisyonu açısından Mısır baskısına göre daha fazla tashih içermektedir. Günümüz İslâm dünyasındaki Sahîh baskılarında daha çok Yûnînînin ana metni kullanıldığından bu makalede Zihni Efendi’nin mezkûr metin bağlamındaki tashihleri ele alınacaktır. Yapılan bu tashihler nüsha farklılıkları ve nüshalardaki hatalarla doğrudan ilgili olduğu için makalede önce Sahîh-i Buhârî nüshalarına dair özet mahiyetinde bilgiler verilecek, ardından tashih olgusu ele alınacak ve Sahîh-i Buhârî nüshalarındaki tashih örnekleri zikredilecektir. Sahîh baskılarının ve Zihni Efendi’nin tanıtıldığı bölümden sonra onun tespit edilebilen tashihleri incelenerek bu tashihlerin isabet durumu tartışlacaktır. Zihni Efendi hakkında ayrıntılı bir çalışma mevcut olduğundan ${ }^{1}$ makalede onun hayatına özetle temas edilip daha ziyade Sahîh çerçevesindeki tashihlerine ağırlık verilecektir.

1 Hamza Ermiş, Mehmed Zihni Efendi - Hayatı, Eserleri ve Arapça Öğretimindeki Yeri, İstanbul: İSAM, 2011. 


\section{Sahîh-i Buhârî Nüshaları Arasındaki Farklar}

\subsection{Sahîh-i Buhârî Nüshaları ${ }^{2}$}

Sahîh-i Buhârî günümüze Firebrî (ö. 320/932) rivayetiyle ulaşmıştır. Buhârînin diğer râvisi İbrahim b. Ma'kil en-Nesefînnin (ö. 295/908) nüshası müstakil olarak mevcut olmasa da hadis şerhlerinde ve diğer kaynaklarda bu nüshanın diğer nüshalardan farklılaştığ 1 noktalar belirtilmiştir. Sahîh'in üçüncü râvisi Hammâd b. Şâkir en-Nesefînin (ö. 311/923) nüshasının farkları ise klasik kaynaklarda nadiren zikredilir. Sahîh’i iki defa dinlediği belirtilen Firebrînnin birçok râvisi vardır. Nüsha farkları konusunda en dikkat çeken isimler ise İbnüs-Seken (ö. 353/964), Müstemlî (ö. 376/986), Serahsî (ö. 381/991), Küşmîhenî (ö. 389/998), Cürcânî (ö. 373/983-4) ve Mervezîdir (ö. 371/982).

Daha sonraki râviler içerisinde Serahsînnin nüshasını nakleden Dâvûdînin (ö. 467/10745) en önemli râvisi Ebü’l-Vakt (ö. 553/1158) ve Küşmîhenînin nüshasını nakleden Kerîme (ö. 463/1071) Sahîh'i tek nüsha olarak yansitan en meşhur isimlerdir. Sahîh'i birden fazla kişiden dinleyen ve bunlar arasındaki farkları tek nüshada yansıtan çalışmaların ilki Asîlî̀ye (ö. 392/1002) aittir. O, Cürcânî ile Mervezî rivayetlerini tek nüshada toplamıştır. Serahsî, Müstemlî ve Küşmîhenîyi tek nüshada toplayan Ebû Zer (ö. 434/1043) ise Sahîh'in genel olarak en sağlam nüshası kabul edilmektedir.

\subsection{Nüsha Farklılıkları}

Sahîh-i Buhârînin nüshaları içerisinde Firebrî ile Buhârî̉nin diğer öğrencileri arasında farkların bulunması gayet doğaldır ve bu durum Mâlik b. Enes'in (ö. 179/795) Muvatta' adlı kitabının farklı nüshalarında olduğu gibi muhtemelen müellifin zamanla yaptı̆̆ı değişiklikleri yansıtmaktadır. Fakat Firebrînnin naklettiği Sahîh-i Buhârî nüshasındaki farklar, Firebrîden ziyade onun râvilerinden kaynaklanır. Bunun temel sebebi olarak ise Sahîh'i iki kez dinlediği belirtilen Firebrînin bu aradaki değişiklikleri yansıttı̆̆ haşiyelerin çok karışık olması akla gelmektedir. ${ }^{3} \mathrm{Bu}$ farklar genellikle bazı mütâbaat ve değerlendirmelerin farklı yerlerde olması veya hiç olmaması, hadislerdeki ve bâb başlıklarındaki ifadelerin değişik olması gibi hususlarda yoğunlaşmaktadır. ${ }^{4}$

2 Burada kısaca değineceğimiz Sahîh-i Buhârî nüshalarıyla ilgili bilgiler bu konuda en ayrıntılı çalışmayı yapan Cuma Fethî Abdülhalîm'in kitabından özetle kaydedilmiştir (bk. Rivâyâtü’l-Câmi 'i’s-sahîh ve nüsehuhû, Misır/ Katar: Dâru'l-Felâh, 2013). Sagânî nüshasına dair bir bilginin bulunmaması gibi bazı önemli eksikleri olmasına rağmen epeyce emek sarf edildiği belli olan bu çalışmada nüshalar çok yönlü tanıtılmaktadır. Türkçedeki tek eser konumunda olan Abdulvahap Özsöy’un Buhârî Nüshaları ve Nüsha Farklılılarının Mahiyeti Üzerine (Kayseri: Fenomen Yayıncılık, 2016) adlı kitabı ise Cuma Fethîden sadece Sagânî nüshasına atıf yapmakla ayrılmaktadır.

3 Farklılı̆̆ın sebeplerinin izah edildiği bir çalışmamız yakın zamanda İFAV tarafından neşredilecektir.

4 Sahîh'in ana bölümlerinin (kitâb) sıralanmasındaki tek fark Oruç bölümünü diğerleri gibi Hac'dan sonra değil de ondan önce zikreden Mervezî nüshasında bulunmaktadır. Firebrînin râvilerinden olan ve muteber bir Şâfiî fakihi olarak ismi geçen Ebû Zeyd el-Mervezînin bu naklinin şahsi bir tasarrufa dayandığı anlaşılmaktadır. Çünkü bilebildiğimiz kadarıyla bu tür bir farklılık başka hiçbir nüshada olmadığı gibi buna dair bir izah da bulunmamaktadır. 
Herhangi bir hatanın bulunmadığı nüsha farklılıkları daha çok olduğundan makalenin içeriğini doğrudan ilgilendiren husus, bazı nüshaların hatalı nakledilmesi sebebiyle oluşan nüsha farklılıklarıdır. Bu hatalar göz kaymasından, harekelemeyi yanlış yapmaktan ya da haşiyeleri yanlış yere koymaktan kaynaklanmaktadır.

\subsection{Nüsha Farklarını Belirten Çalıșmalar}

Nüshalar arasındaki farkları gösteren çalışmaların Asîlî ve Ebû Zer nüshaları ile başladığını belirtmiştik. Bunlardan sonra farkları gösterme faaliyeti "sadece farklar üzerinde duran müstakil çalışmalar", "birden fazla nüsha içerip aralarındaki farkları gösteren nüshalar" ve "Sahîh'in şerhi sırasında bu farkları özellikle belirten hacimli eserler" şeklinde devam etmiştir.

\subsubsection{Müstakil Çalışmalar}

Endülüs bölgesinin orijinal çalışmalarından birisi olan "nüshalar arasındaki farkları ve bunlardaki hataları gösteren" müstakil eserler Ceyyânînin (ö. 498/1105) Tenbîh ile onun talebesi Kadı İyâz’n (ö. 544/1149) Meşârık adlı kitaplarıdır. ${ }^{5}$ Sahîh-i Buhârî, Sahîh-i Müslim ve Muvatta' nüshalarının değerlendirildiği bu eserlerde Ceyyânî daha çok senedler üzerinde yoğunlaşmış, Kadı İyâz ise bunu daha geliştirmiş ve kelimeleri alfabetik olarak ele alarak metin farklılıklarını da belirtmiştir. Gerek hadis konusundaki uzmanlıkları gerekse diğer birikimleri sayesinde bu kitaplar sonrakiler için çok önemli kaynaklar haline gelmiştir.

Bunlardan sonra bu konuda çalışma yapan İbn Kurkul'un (ö. 569/1173) Metâli‘ adlı eseri kanaatimizce Kadı İyâz’’n kitabının kötü bir kopyası, İbnü’l-Mebrid olarak bilinen İbn Abdilhâdî̉nin (ö. 909/1503) İhtilâf adlı eseri de Ceyyânînnin kitabının Sahîh-i Buhârî̀yle ilgili kısmının özeti konumunda olduğundan makalede ayrıca ele alınmaya gerek görülmemiştir. ${ }^{6}$

\subsubsection{Nüshalar}

Sahîh'i rivayet ederken diğer nüshaların farklarını gerek metin üzerinde ve gerekse kenardaki notlarda (hamiş) gösteren çalışmalar Asîlî ve Ebû Zer'den sonra nispeten gelişme göstererek devam etmiştir. Bunların en önemlileri Sagânî ve Yûnînî nüshaları ile Sehârenfûrî haşiyesidir.

5 Ebû Alî el-Ceyyânî el-Gassânî, Kitâbü't-Tenbîh ale'l-evhâmi'l-vâki'a fi's-Sahîhayn min kıbeli'r-ruvât, Kısmu'l-Buhârî (nşr. Mehmed Sâdık Aydın), Riyad: Dâru'l-Livâ, 1987; Kadı İyâz, Meşâriku'l-envâr alâ sıhâhi'l-âsâr (nşr. Ahmed Sâlih eş-Şâmî), I-III, Dımaşk: Dâru'l-Kalem, 2012.

6 İbn Kurkul, Metâli'u'l-envâr alâ sıhâhi'l-âsâr (nşr. Ahmed Uveys el-Cüneydî - v.dgr.), Misır: Dâru'l-Felâh, 2012; İbnü'l-Mebrid, Yusuf b. el-Hasan, el-İhtilâfbeyne ruvâti'l-Buhârî ani'l-Firebrîve rivâyât an İbrahim b. Ma'kıl en-Nesefî (nşr. Salâh Fethî Helel), Riyad: Dâru'l-Vatan, 1999. Kitabın yazarı İbnü'l-Mibred olarak da telaffuz edilmektedir; fakat eserin muhakkiki bizzat İbnü'l-Mebrid'in talebesinin kitabından naklettiği okuyuşun bu şekilde olduğunu söyler (s. 10). 


\subsubsection{Sagânî Nüshası}

Meşhur bir dilci olan Radıyyüddin Hasan b. Muhammed es-Sagânî (ö. 650/1252), Buhârî hayatta iken yazıldığı söylenen ve üzerinde Firebrînin kendi hattıyla tashih kaydı bulunan eski bir nüsha ${ }^{7}$ ile Ebû Zer rivayetindeki üç nüshanın farklarını gösterdiği bir çalışma yapmıştır. Önemli olmasına rağmen İslâm dünyasında pek bilinmeyen bu nüshayı İbn Hacer (ö. 852/1448) şerhinde kullanmış ve ona itibar etmiş, böylelikle nüshanın ilmî değerinin bir nebze bilinmesini sağlamıştır.

Günümüzde bu nüshayı ilim çevrelerine tekrar tanıtan kişi, birazdan değineceğimiz Sehârenfûrî haşiyesini tahkik eden Takıyyüddin en-Nedvîdir. Hindistan'daki Sagânî nüshasını inceleyen Nedvî sadece bu nüshada bulunan açıklamalardan tespit edebildiklerini de mukaddimesinde belirtmiştir.

Sagânî nüshasıyla ilgili en ayrıntılı çalışmayı ise Türkiye’deki Sagânî nüshalarını keşfeden Arafat Aydın yapmıştır. ${ }^{8}$ Bu çalışmada kullandığımız Sagânî nüshası da Türkiyede bulunan ve titizlikle yazıldığ

\subsubsection{Yûnînî Nüshası}

Ali b. Muhammed el-Yûnînî (ö. 701/1301) ulaşabildiği önemli Buhârî nüshaları arasındaki farkları tek nüshada yansıtmış ve bu nüshanın tashihi için uzun yıllar çalışmıştır.

Yûnînî nüshasındaki ana metni, Ebü’l-Vakt'in onayından geçmiş olan Kerîme nüshası oluşturmaktadır. ${ }^{10} \mathrm{Bu}$ sebeple çoğu zaman Kerîme nüshasıyla, kimi zaman da Ebü’l-Vakt nüshasıyla uyuşmaktadır ki, tashihler incelenirken bunların bir kısmı görülecektir. Yûnînî bu nüsha ile Ebû Zer, Asîlî, İbn Asâkir (ö. 571/1175) ve Semânî (ö. 562/1167) nüshaları arasındaki farkları tek tek, harf harf göstermiştir. Her birinin hadis hafızı olması ve nüshaların çok titizlikle yazılmaları sebebiyle Yûnînînin çok önemsediği ${ }^{11}$ bu dört nüshanın farklarının gösterilmesi, kanaatimizce bugünkü tahkik çalışmalarının bir benzeri niteliğindedir ve Yûnînî nüshasının değerini arttıran bir husustur.

Yûnînînin bu gayreti ve titizliği, gerek kopyalarının yaygınlı̆̆ının gerekse matbaa döneminde bu nüshanın tercih edilmesinin gösterdiği üzere teveccühle karşılanmıştır.

7 İbn Hacer bunu "Bağdat nüshası” olarak isimlendirmektedir (bk. Fethu'l-Bârî şerhu Sahîhi’l-Buhârî, I-XIII, Lübnan: Dâru İhyâi't-Türâsi'l-Arabî, 1982, I, 125 [Kitâbü'l-ilm, Bâbu mâ câe fi'l-'ilm]).

8 Arafat Aydın, Sagânînin Sahîh-i Buhârî Nüshası Ve Türkiye Kütüphanelerindeki Yazmaları (uzmanlık tezi), [İstanbul: Türkiye Yazma Eserler Kurumu Başkanlığı, 2016].

9 Süleymaniye Yazma Eser Kütüphanesi, Damad İbrahim, nr. 266-269.

10 Bunun ayrıntıları için bk. Arafat Aydın - Ali Albayrak, "Sahîh-i Buhârî Nüshalarına Dair Yeni Bulgular: Bulak Baskısı, Yûnînî Yazmaları ve Abdullah b. Sâlim el-Basrî Nüshası”, İslâm Araştırmaları Dergisi, 2016, sy. 35, s. 7-8. 
İleride ayrıntılarına değineceğimiz üzere Mısır'da gerçekleştirilen Sahîh baskısında da Yûnînî nüshası kullanılmış, günümüzde de bu baskının birçok tıpkıbasımı yapılmıştır. ${ }^{12}$

Yûnînî nüshası önemli olmakla beraber kendi nüshasını yansıtan ana metin birtakım hatalar içermektedir ve gerek Yûnînînin kaydettiği diğer nüshaların gerekse birçok alıntıyla işaret ettiği notların dikkate alınmaması sonucunda bugünkü Sahîh baskılarının çoğunda bu hatalar devam etmektedir ki, bunların bir kısmı bu çalışmada dile getirilecektir.

Yûnînî nüshasının en önemli kopyası, Abdullah b. Sâlim el-Basrînin (ö. 1134/1722) Yûnînînin aslından yazdığı ve iki kopyasıyla karşılaştırdığı nüshasıdır. Bu nüshanın tashihiyle yirmi yıl kadar uğraştığı belirtilen Basrî, Yûnînînin gösterdiği ihtimamın bir benzerini göstermiş ve Buhârî şârihlerinden yaptığı alıntılarla birçok noktayı açılamaya çalışmıştır. Basrî nüshasının Türkiyede birçok kopyası mevcuttur. Bu çalışmada kullanacağımız nüsha Konya’da bulunan ve gerçekten çok güzel yazılıış olan kopyasıdır. ${ }^{13}$

\subsubsection{Sehârenfûrî Haşiyesi}

Sagânî ve Yûnînî nüshalarına ulaşan Hindistanlı âlim Ahmed Ali es-Sehârenfûrî (ö. 1297/1880) şerhlerdeki bilgileri de derleyerek Sahîh-i Buhârî nüshaları arasındaki farkları yansitan en ayrıntılı çalışmayı yapmıştır. Sehârenfûrî, yaptığı edisyonu kendi hâş̧iyeleriyle birlikte büyük boy iki cilt halinde Delhi'de 1851-1853 yılları arasında basmak suretiyle dünya üzerindeki ilk basılı Sahîh-i Buhârî neşrini gerçekleştirmiştir. El yazısından yapılan bir baskı olması sebebiyle karışık bir görünüm arz eden bu hâşiyeli Sahîh-i Buhârî nüshası, kenarlardaki bilgilerin dipnotlar haline getirildiği güzel bir tahkikle 15 cilt halinde yeniden basılmıştır. ${ }^{14}$

Sehârenfûrînin elinde Yûnînînin Basrî kopyası bulunsa da asıl itibar ettiği Sagânî nüshasıdır ve bu sayede birçok hatayı tashih etmiştir. Hatta diyebiliriz ki, bugüne kadar yapılan Sahîh-i Buhârî baskıları içerisinde en az hata Sehârenfûrî neşrindedir. ${ }^{15}$

\subsection{3. Şerhler}

Ayrıntılı Buhârî şerhleri içerisinde nüsha farklarına değinen müelliflerin başında İbn Hacer (ö. 852/1448) ile Kastallânî (ö. 923/1517) gelmektedir.

12 Bu çalışmada Âsitâne Kitabevi’nin baskısı kullanılmıştır: Sahîhu’l-Buhârî (İstanbul/Üsküdar: 2003). Bundan sonra kısaca Âsitâne olarak anılacak bu baskının makaleyle ilgili bölümleri, Yûnînî nüshasının meşhur kopyaları olan Basrî, Nüveyrî, Bedrânî ve Mizzî yazma nüshalarıyla karşılaştırılmıştır. Yûnînî nüshasının kopyaları için bk. Aydın - Albayrak, "Sahîh-i Buhârî Nüshalarına Dair Yeni Bulgular", s. 11-19.

13 Konya Yusuf Ağa Yazma Eser Kütüphanesi, nr. 5555.

14 Ahmed es-Sehârenfûrî, el-Câmi'u's-sahîh bi-hâşiyeti'l-muhaddis es-Sehârenfûrî (nşr. Takıyyüddin en-Nedvî), I-XV, Beyrut: Dâru'l-Beşâiri'l-İslâmiyye, 2011.

$15 \mathrm{Bu}$ durum Sahîh-i Buhârî baskılarının karşılaştırmalı olarak incelendiği çalışmamızda ayrıntılı olarak incelenmektedir. Konu hakkında ayrıca bk. Mehmet Özşenel, "Sahîh-i Buhârî Neşirleri: Sehârenpûrî Neşri ile II. Abdülhamid Neşrinin Karşılaştırılması”, Türkiye Araștırmaları Literatür Dergisi, 2013, XI, sy. 21, s. 454-484. 


\subsubsection{1. İbn Hacer}

Şerhini Sahîh-i Buhârînin en sağlam rivayeti olarak kabul ettiği Ebû Zer nüshasına göre yapan İbn Hacer birçok nüshadan haberdar olup bu nüshalar arası farklara çoğunlukla değinmekte ve şayet hata varsa bunu özellikle belirtmektedir. Kendisinin bizzat dinlediği Ebû Zer nüshası olan Ebû Zer'in oğlu Ebû Mektûm İsa (ö. 497/1104) rivayeti yanında meşhur Mâlikî fakihi Ebü’l-Velîd el-Bâcînin (ö. 474/1081) nüshasını16 kullanmış ve kimi zaman bu nüshadaki notları nakletmiştir. Yûnînî nüshasını aslından okumasına rağmen Sagânî nüshasını tercih etmiş ve Sagânînin farklarına işaret ettiği Firebrî onaylı nüshada bulunan ilave izahları çoğunlukla nakletmiş, hatta bazı sorunlu yerleri buradaki bilgilerle çözmüştür.

Nüshalar dışında Sahîh-i Buhârî ile ilgili çok önemli kaynaklar konumunda olan müstahreclere ve özellikle İsmailî̀nin (ö. 371/992) müstahrec çalışmasına, asıl ve tali birçok hadis kitabına vâkıf olan İbn Hacer hataları belirlemede en önemli kaynak konumundadir.

\section{3.3.2 Kastallânî}

Kastallânî nüsha farklarına muhakkak değindiği şerhinde ${ }^{17}$ genellikle İbn Hacer'den nakilde bulunmaktadır. Onu burada ayrıca zikretmemizin sebebi, şerhini Yûnînî nüshası üzerinden yapmasıdır. ${ }^{18} \mathrm{Bu}$ şekliyle hem İbn Hacer'in değinmediği bir nüshaya değinmiş olmakta hem de bugünkü Buhârî baskılarında temel kabul edilen Yûnînî nüshasıyla ilgili en önemli kaynak konumuna gelmektedir. ${ }^{19}$ Metin olarak Yûnînî nüshasındaki ana metni kullanmasına rağmen kimi zaman İbn Hacer'in izahları doğrultusunda diğer nüshalarda bulunan ibareyi tercih etmiş, böylelikle Yûnînînin ana nüshasından farklı ve daha doğru bir Sahîh metni ortaya çıkmıştır. Nitekim İbn Hacer ve Aynî (ö. 855/1451) şerhlerine eklenen Sahîh-i Buhârî metinlerinde ve ileride göreceğimiz gibi Zihni Efendi’nin tashihlerinde Kastallânînin metni ve yorumları tercih edilmiştir.

\section{Tashih Olgusu}

Bu bölümde tashihle ilgili kavram ve olgulara kısaca değinildikten sonra matbaa dönemi öncesinde gerçekleşen tashih uygulamaları ve uyarılarına dair örnekler verilecektir.

16 Ondan nakleden Ebû Ali es-Sadefî (ö. 514/1120) olduğundan "Sadefî nüshası" olarak bilinmektedir.

17 Ahmed b. Muhammed el-Kastallânî, İsşâdü’s-sârî li-şerhi Sahîhi’l-Buhârî̀, I-X, Beyrut: Dâru İhyâi’t-Türâsi'l-Arabî, ts.

18 Kastallânî, İrşâd, I, 40-1.

19 Aslında Yûnînî nüshasıyla ilgili en önemli kaynak yukarıda zikri geçen Basrînin tamamlanamayan Buhârî şerhidir (bk. Abdullah b. Sâlim el-Basrî, Dıyâü's-sârî fî mesâliki ebvâbi Sahîhi'l-Buhârî [nşr. Nûreddîn Tâlib], I-XVIII, Katar: Dâru'r-Rakîm, 2011). 


\subsection{Galat, Tashîf, Tahrîf}

Hadislerin nakli sırasında hataların olması kaçınılmazdır. Meşhur muhaddislerin bile yaptığı bu hatalar ancak çok olması durumunda zayıflık sebebi kabul edilmektedir. Tanım ve ifadeler kimi kaynaklarda farklılaşsa da genel olarak galat kelimesiyle ifade edilen bu hatalar "harflerin noktaları veya harekeleri değiştirilerek nakledilmesi" şeklindeyse tashîf, daha farklı bir değiştirmeyse tahrif olarak isimlendirilmiştir. ${ }^{20}$ Örneğin İbn Hacer, Buhârînin bir tercemede (Menâkıb, 4) zikrettiği Eslem b. Efsâ isminin Cürcânî nüshasında Ef â olarak nakledilmesinin tashîf olduğunu söyler. ${ }^{21}$ Yine İbn Hacer "haddesenâ Süleyman b. Harb 'an Şu'be 'ani'l-Hakem" senedindeki Şu'be isminin Küşmîhenî nüshasında Saîd olarak geçmesini "galat-1 fâhiş" olarak niteleyip bunu şöyle izah etmiştir: "Süleyman b. Harb'in şeyhleri arasında Sa îd isminde olup da Hakem'den nakilde bulunan herhangi birisi yoktur." 22

Burada bizim için önemli olan husus tanımlar veya neyin nasıl ifade edildiği değil, hadislerin yazımı ve nakli sırasında yapılan bu tür hataların varlığıdır. Bunların bir kısmı yazının, yani noktalama ve harekelemenin gelişmediği veya çok yaygın olarak kullanılmadığ 1 ilk dönemlerin ürünüdür. Diğer kısmı ise yazım sırasında yapılan yanlışlıklardır ki, bu her dönem olabilecek bir kusurdur.

Hadisleri nakleden râvilerin hatalarının düzeltilmesi tartışma konusudur. ${ }^{23}$ Fakat kitapların nakli sırasında yapılan hatalar kesinlikle düzeltilmelidir. Tashih denilen bu düzeltme işlemi aşağıda göreceğimiz üzere birkaç şekilde olmaktadır.

\subsection{Nüshaların Tashihi}

Bir nüshanın tashihi ya yazan kişi tarafından ya da daha sonra bunu okuyan bir âlim tarafindan yapılır. Sadece dil uzmanlarının yaptığı tashihler de mevcuttur. Bu tashihlerin ayrıntıları, özellikle Sahîh-i Buhârî nüshaları üzerinde yapmış olduğumuz çalışmalar sonucunda elde ettiğimiz bilgilere göre kısaca şu şekildedir:

\subsubsection{Asla Bakarak Tashih}

İstinsah edilecek, yani aynısı yazılacak olan nüshaya asıl (asl) denir. Bu asıldan yazılacak nüsha ise kopya ( $f e r)$ adını alır. ${ }^{24}$ Fakat asıl ve kopya kavramları izafidir; çünkü her bir kopya aynen yazılacağı zaman asıl adını alır. Mesela Yûnînî nüshasının birçok kopyası vardır. Bu kopyalardan en meşhuru olan Basrî nüshasının da birçok kopyası yazılmıştır ve Basrî nüshası Yûnînî nüshasına göre kopya, kendi kopyalarına göre asıl olmaktadır. Yûnînî

20 Ayrıca bk. Emrullah İşler, “Tashîf”, DİA, XL, 128.

21 İbn Hacer, Fethu'l-Bârî, VI, 420.

22 Âsitâne, III, 30, 7. hamiş (Âsitane diye andığımız neşir, Bulak baskısının tıpkıbasımı olduğundan, sayfa numarası dâhil her yönüyle Bulak baskısının veya herhangi bir tıpkıbasımının aynısıdır). 
nüshasının kopyalarına Yûnînî nüshası denmesinde olduğu gibi kopyalara genellikle asıl nüshanın adıverilir. Şayet kopyalar birden fazla kişi tarafından yazılmışsa önemli kopyalar için ayrı bir isim kullanılması da vakidir.

Nüsha yazılırken başka nüshalarda farklı olan veya karışıklık olması muhtemel yerlere sah (sahîh) kaydı konur. Bu kayıt, ilgili kelimenin özellikle kontrol edildiğini ve asıldaki ibarenin böyle olduğunu ifade eder. Şayet bu asıldaki kelimede bir gariplik varsa ve nüshayı kopyalayan kişi bu asılda bir hata olabileceğini belirtmek istiyorsa tadbîb işareti, yani yarım sâd harfi koyar ve böylece "asılda bu şekilde geçtiğini ama burada bir sorun olduğunu" ifade etmiş olur.

Bir nüsha kopya edildikten sonra asla bakılarak tekrar gözden geçirilmeli ve yanlışlar varsa tashih edilmelidir. Titizlikle yazılmış nüshalarda her hadisten sonra bir daire işareti vardır ve bunların içine de bir nokta konmuştur. Bu daireler nüsha yazılırken boş bırakılır ve kontrol edildikçe içlerine noktalar konur. ${ }^{25}$

\subsection{2. Âlimlerin Tashihi}

Kitaplar istinsah edilirken esas olan, kitabın aynen yazılmasıdır; âlim olmayan bir müstensihin anlamı kontrol ederek yazması mümkün değildir. Daha sonra bu nüshaları okuyan ilim ehli gerekli düzeltmeleri kenarlara kaydetmişlerdir. Bu yüzden bir nüshanın güvenilirliği, nüshada bulunan semâ‘ kaydındaki muteber âlimlerin isimleriyle doğrudan alakalıdır. Kimlerin bu nüshayı baştan sona dinlediğini gösteren söz konusu kayıtlarda hadis hâfızlarının isminin bulunması, bu nüshanın onların onayından geçtiğini göstermektedir.

Bir kitabı yazan veya rivayet eden muhaddisin tashih kaydı veya dışarıdan dinleyen bir âlimin semâ‘ kaydı kanaatimizce nüshada hiçbir hatanın olmadığının göstergesi değildir. Çünkü konu üç beş sayfalık bir yazı değil, yüzlerce sayfadan ve binlerce rivayetten oluşan bir kitaptır ve bunun baştan sona bu kişiler tarafından ayrıntılı bir şekilde kontrol edilmesi mümkün değildir. Tashih ve semâ‘ kayıtlarının genel bir tashihi yansıttığg unutulmamalıdır.

\subsubsection{Dilcilerin Tashihi}

Hadisin veya nüshanın nakli sırasında dil açısından yanlışlıklar olabileceğinden hadisle ilgilenen dilcilerin tashihine ayrı bir önem verilmiştir. Nitekim Yûnînî, dönemin en ünlü dilcisi İbn Mâlik’e (ö. 672/1273-4) nüshasını okumuş ve onun yorumları doğrultusunda bazı tashihlerde bulunmuştur. ${ }^{26}$ Yukarıda belirttiğimiz gibi önemli bir dilci olan Sagânî ise nüshasının kenarında "bütün nüshalarda böyledir ama aslında şöyle olmalıdır" türü notlarla dil yanlışlıklarına dikkat çekmiştir. ${ }^{27}$

25 Yazma eserler içerisinde belli bir yerden sonra bu noktaların konulmadığı nüshalar da mevcuttur; bu durum kontrol işleminin yarım kaldığını gösterir.

26 Tespit edebildiğimiz tek tashih örneği için bk. Âsitâne, IV, 187. Yûnînînin bu tashihe verdiği önem İbn Mâlik’le yapmış olduğu bu oturumları nüshasının baş kısmına kaydetmiş olmasından anlaşılmaktadır.

27 Bunun örnekleri için bk. Aydın, Sagânînin Sahîh-i Buhârî Nüshası, s. 71-3. 


\subsection{Sahîh-i Buhârî Nüshalarında Tashih}

Yukarıda belirtildiği gibi Sahîh'in nüshaları arasındaki farklara değinen isimler nüshalardaki hatalara çoğunlukla işaret etmiştir. Müstakil çalışma yapanlar ve Buhârîye şerh yazanlar yanlı̧̧ sadece belirtirken nüsha sahipleri veya bunların râvileri kimi zaman bu tür bilgilerle nüshalarını düzeltmiştir. Sahîh-i Buhârrîaçısından önemli olan bazı isimlerin tashih örneklerini zikretmemiz, gerek nüsha farklarının mahiyetini kavramamıza gerekse tashih olgusunu daha somut olarak görmemize yardım edecektir.

\subsubsection{Ceyyânî (̈̈. 498/1105)}

Tespit edilebildiği kadarıyla "nüshalar arasındaki farkları ele alıp hatalı olanları tespit etme" konusunda dikkat çeken ilk kişi Endülüslü âlim Ebû Ali el-Ceyyânî el-Gassânîdir. Yûnînî onun tashih uyarılarının bir kısmını nüshasının kenarlarında zikretmiştir. Yûnînînin gözden kaçırdığı yerlere örnek olarak şu haber zikredilebilir: Ceyyânî 7350. hadisin (İ'tisâm, 20) senedinde Süleyman b. Bilal isminin Firebrî nüshasında düştügünü, Nesefî nüshasında ise mevcut olduğunu söylemiş ve bu ismin muhakkak olması gerektiğini vurgulamıştır. ${ }^{28}$

\subsubsection{Kadı İyâz (ö. 544/1149)}

Kadı İyâz, Sahîhayn ve Muvatta hadislerindeki garib kelimelerin izahı yanında lafızların tashih ve zaptına tahsis ettiği eseri Meşâriku'l-envâr alâ sıhâhi'l-âsâr adlı eserinde pek çok tashih örneği vermiştir. Bunlardan biri bizzat Yûnînînin Kadı İyâz'dan aktardığı şu örnektir: Hac, 63 ve 78'deki rivayetlerde Urve b. ez-Zübeyr'in sümme hacectu me'a Ebi'z-Zübeyr ifadesi bulunmaktadır. Küşmîhenî ise muhtemelen bunun ebî ez-Zübeyr (babam Zübeyr) anlamında olduğunu fark edemeyip tâbiînden olan Ebü’z-Zübeyr ismini burada garipsemiş ve iki yerde de méa İbni'z-Zübeyr şeklinde nakletmiştir. Kadı İyâz bu rivayetin bir tashif olduğunu belirtmektedir. ${ }^{29}$

\subsubsection{Sagânî (ö. 650/1252)}

Sagânî daha çok dil yanlışlarına dair uyarılarda bulunmakla beraber rivayetlerle ilgili yanlışlara da işaret etmiştir. Mesela 1758. hadiste (Hac, 145) kendi nüshasında Ümmü Seleme ismi vardır. Sagânî diğer nüshalarda Ümmü Süleym isminin geçtiğini ve doğrusunun bu olduğunu belirtmiştir. ${ }^{30}$

İbn Hacer, Fethu'l-Bârî, XIII, 270. İbn Hacer elindeki nüshalarda bu ismin bulunduğunu söyleyerek itiraz etmektedir; ancak ileride değineceğimiz gibi Yûnînî nüshasında da bu isim yoktur. bu ismi “İbni’z-Zübeyr” şeklinde kaydetmiştir (Sahîhu’l-Buhârî [Zihni Efendi neşrinin tıpkıbasımı], I-VIII, İstanbul: Çağrı Yayınları, 1992, II, 163, 169. Bu kaynak bundan sonra Çağrı olarak ifade edilecektir). 


\subsubsection{Yûnînî (ö. 701/1301-2)}

Nüshası üzerinde yapmış olduğumuz incelemeye göre Yûnînî kendi nüshasını "olduğu gibi” nakletmeyi amaç edindiğinden genelde tashihe gitmemiş, ama çok önemsediği diğer nüshalara ve Ceyyânî, Kadı İyâz gibi muteber isimlerin izahlarına bakarak hatalı olan yerlere muhakkak işaret etmiştir. Nitekim bir yerde geçen hattâ lekad raeytü ürîdü en âhuze ifadesi için kenarda şu notu düşmüştür: "Humeydînnin [ö. 488/1095] el-Cem' beyne's-Sahîhayn'inde hattâ lekad raeytünî ürîdü en âhuze şeklinde geçmektedir ki, doğrusu da budur." ${ }^{31}$ Yine 5568. hadisin (Edâhî, 16) metninde geçen Ebû Katâde ismiyle ilgili olarak Yûnînî doğrusunun Katâde olduğunu ve bu hadisin bir tekrarında (hadis no. 3997: Megâzî, 12) bu şekilde geçtiğini kenarda belirtmiştir. ${ }^{32}$

Bunların yanında bizzat düzelttiği bazı yerler de mevcuttur. Mesela bir yerde kendi nüshasında "en-Nadr" olarak geçen ismin "el-Basrî" lafzından bozma bir hata olduğunu ve bu durumun hâfız imamların nüshalarından tahkik edildiğini söyler, kendi metnini de "elBasrî” olarak kaydeder. ${ }^{33}$

Bir de Yûnînînin ayrıca değinmediği ama Basrînin notlarından anlaşıldığına göre nüsha üzerinde sonradan düzelttiği bazı tashih örnekleri vardır. Örneğin metinde Cibrîl olarak geçen ve kenarda "bir nüshada habr şeklinde olduğu” belirtilen bir kelime, Basrînin anlattığına göre metne sonradan müdahaleyle habr şekline dönüştürülmüştür. ${ }^{34}$ Bunun sonradan olduğu şuradan da bellidir ki, başka bir nüshada ne yazdığını kenarda göstermek için ana metinden bir farkı olması gerekmektedir; hâlbuki mevcut durumda iki kelime arasında bir fark bulunmamaktadır. ${ }^{35}$

\subsection{5. İbn Hacer (ö. 852/1448)}

İbn Hacer kendi metnini oluşturmadı̆̆ından Buhârînin nüshası üzerinde herhangi bir tashihte bulunmamışsa da Fethu'l-Bârî adlı şerhinde sayısız tashih uyarısı yaptığı görülür. Nitekim o Sahîh'teki 1373. hadisin (Cenâiz, 86) sonunda bulunan zâde Gunder 'azâbu'l-kabri şeklindeki mütâbaatın burada bulunmasının galat olduğunu, bazı nüshalarda 1372'nin sonunda bulunduğunu ve doğrusunun bu olduğunu belirtir. ${ }^{36}$ Çünkü Gunder, yani Muhammed b. Ca'fer, Şu'be’nin en meşhur râvisidir ve Şu'be rivayeti, 1372. rivayettir. 1373'ün ne Şu'be’yle ne de Gunder'le bir ilgisi vardır.

31 Âsitâne, II, 65.

32 Âsitâne, VII, 103. Zihni Efendi de benzer bir açıklama yapmıştır (bk. Çağrı, VI, 239).

33 Konya, Yusuf Ağa, nr. 5555, vr. 289². Yûnînînin bu izahı Ezherli âlimlerce hazırlanan Buhârî baskısında yer almaz (bk. Âsitâne, IV, 151). olarak nitelediğini” naklettiği cümleleri aynen kaydetmişlerdir (Âsitâne, IX, 134). 
İbn Hacer'in çok ayrıntılı bir şekilde tahkik ettiği yerlerden biri 1168. hadisin (Teheccüd, 26) senedinde bulunan hatadır. Buradaki senedin haddesenâ Süfyân kâle Ebün-Nadr haddesenî ebî 'an Ebî Seleme kısmında geçen ve sadece bazı nüshalarda bulunan ebî lafzının yanlış olduğunu belirtirken şunları zikreder: Süfyan b. Uyeyne’nin naklettiği bu rivayet biraz önce geçmiştir (1161: Teheccüd, 24) ve orada Ebün-Nadr bu hadisi arada babası olmaksızın Ebû Seleme'den nakletmiştir. Humeydî bu hadise Müsned inde yer verir; orada da Ebü’nNadr bunu Ebû Seleme'den rivayet eder. Ayrıca Ebü’n-Nadr'ın ne bu hadiste ne de başka bir hadiste babasından rivayeti bulunmaktadır; kim bunu eklerse hata yapmıştır. ${ }^{37}$

İbn Hacer'in tashih örneklerinden biri de Yûnînî nüshasının aslına kendi el yazısıyla yazdığ 1 nottur. Burada Yûnînî bir tercemede ${ }^{38}$ geçen 'an Ömer ve'bni 'Avf ifadesiyle ilgili olarak Kadı İyâz’dan "bunun yanlıs yazıldığı, doğrusunun da Amr b. Avf olduğu" izahını nakletmektedir. İşte İbn Hacer bu notun hemen altında "söz konusu rivayetin Amr b. Avf el-Müzenîden nakledilmiş olduğunu" belirterek Kadı İyâz’n tashihini teyit etmekte, ${ }^{39}$ şerhinde ise "bazı nüshalarda 'an Ömer şeklinde geçtiğini ama bunun yanlış olduğunu" açıkça söylemektedir. ${ }^{40}$

\subsubsection{Abdullah b. Sâlim el-Basrî (ö. 1134/1722)}

Yûnînî nüshasının en önemli kopyasını yazan Basrî için de önemli olan, bu nüshayı "olduğu gibi" nakletmektir. Aslını bu şekilde naklettiği gibi, iki kopyası ile bu asıl arasındaki farkları da titizlikle göstermiştir. Yirmi yıl kadar bu nüsha üzerinde çalışı̆̆̆ nakledilen Basrî, bu süreç içerisinde İbn Hacer ve Kastallânîden alıntılar yaparak hatalı gördüğü yerleri dipnotlarda belirtmiştir. Örneğin Basrî 1558. hadisin sonunda bulunan ve zâde Muhammed b. Bekir mütâbaatını naklettikten sonra "Yûnînî nüshasında bunun burada sah kaydıyla dipnot olarak bulunduğunu ama bazı nüshalarda haddesenâ el-Hasen sözünden önce [1557’nin sonunda] nakledilmiş olduğunu ve Fethu'l-Bârînin de buna delalet ettiğini” söylemiş ve "çünkü bu fazlalık Enes hadisiyle değil, Câbir hadisiyle alakalıdır” izahını yapmıştır. ${ }^{41}$ Biraz sonra göreceğimiz üzere Bulak baskısındaki tashihlerin önemli bir kısmı Basrînnin notları doğrultusunda yapılmıştır.

37 İbn Hacer, Fethu'l-Bârî, III, 35 (bu şerhe sonradan eklenen metinde eb̂̂ lafzı kaldırılmıştır). Zihni Efendi burayı tashih etmeden nakletmiştir (Çağrı, II, 52).

38 Buhârî, Hars 15 (2335. hadisten önce).

39 Konya, Yusuf Ağa, nr. 5555, vr. 188 .

40 İbn Hacer, Fethu'l-Bârî, V, 14. Ezherli âlimler, Kastallânîden bu yönde açıklamalar nakletmelerine rağmen herhalde bütün nüshalarda böyle olduğundan herhangi bir tashihte bulunmamışlardır (Âsitâne, III, 106). Zihni Efendi de tashih yapmamayı tercih etmiştir (Çağrı, III, 70).

41 Âsitâne, II, 140. 


\section{Matbaa Döneminde Sahîh'in Tashihi ve Zihni Efendi}

\subsection{Sahîh-i Buhârî Baskıları}

Bilebildiğimiz kadarıyla Sahîh-i Buhârî İslâm dünyasında ilk defa Hindistan'da, yukarıda değindiğimiz Ahmed Ali es-Sehârenfûrî tarafından basılmıştır (1270/1853). Bu baskıdaki ana metnin hangi nüshaya dayandığı net değildir. Elinde Yûnînî ve Sagânî nüshaları mevcut olan Sehârenfûrînin hadis ehlinin pek kullanmadığı "karma bir metin oluşturma" yolunu izlemesi ihtimal dâhilindedir; çünkü Yûnînînin ana metninde bulunan hataların birçoğu bu baskıda yoktur ancak Sagânî nüshasından ayrıştığı yerler de mevcuttur.

Mısır'daki ilk baskı Hindistan'dan on sene sonra yapılmıştır. 1280/1863 yılında Dâru'tTibấa el-Kübrâ el-Misriyye'de yapılan üç ciltlik bu neşrin musahhihi Muhammed Kitta elAdevî (ö. 1862) ${ }^{42}$ iç kapaktaki ifadelerinde "bu baskıyı istisnai durumlar haricinde Kastallânî şerhindeki metne göre yaptıklarını” söylemekte, üçüncü cildin en sonundaki izahta da "kitabın tashihi için çok emek sarf ettiklerini" belirtmektedir. ${ }^{43}$ Bu neşirde ilk defa Kastallânî şerhi içerisindeki ana metin nakledilmiş ve hamişlerde de metinle ilgili çeşitli açıklamalarda bulunulmuştur. Fakat Sahîh metni harekeli değildir.

Sahîh'in en bilinen baskısı Sultan II. Abdülhamid tarafından Ezherli âlimlere yaptırılan ve Bulak'taki Emîriye Matbaası’nda basıldığından "Bulak Baskısı" olarak bilinen neşirdir (1313/1895). Bu neşirde Yûnînî nüshasının Basrî kopyası kullanılmış ancak Ezherli âlimlerin özellikle belirttiği kimi yerlerde başka kopyalar ve nüshalar tercih edilerek metin tashih edilmiştir.

Sahîh'în bir diğer basımı İstanbul'da Mehmed Zihni Efendi tarafından gerçekleştirilmiştir. Son kısımda inceleyeceğimiz bu baskıda Zihni Efendi tarz olarak Adevî neşrini benimsediğinden nüsha farklarını nadiren yansıtmış, hamişlerde daha ziyade metinle ilgili açıklamalarda bulunmuştur. Adevî neşrinden farklı olarak o, Bulak neşrindeki harekelemeyi kendi neşrine taşımıştır.

Bugünkü Sahîh baskılarının neredeyse tamamında ve Buhârî şerhlerine eklenen metinlerde Bulak neşri kullanılmaktadır.

\subsection{Bulak Baskısında Tashih Örnekleri}

Ezherli âlimlerin yapmış olduğu bu baskıda Yûnînî ile Basrînin kenardaki notları doğrultusunda ve Yûnînî dışındaki nüshalara uygun olarak bazı tashihler yapılmıştır. Doğrudan konumuz olan bu tashihlerden tespit edebildiklerimiz şunlardır:

- Yûnînînin aslında 891. hadis (Cumúa, 10) haddesenâ Muhammed b. Yûsuf şeklinde başlamaktadır. Kenarda ise bütün nüshaların hamişinde haddesenâ Ebû Nuaym olarak

42 Baskı ve ölüm tarihleri bu şekildedir. Muhtemelen bu neşir onun vefatının ardından basılabilmiştir.

43 Bu baskı Süleymaniye Kütüphanesi'nde mevcuttur (bk. Hidiv İsmail, nr. 14). 
yazdığı açıklaması ve tashih kaydı vardır. Bu açıklamaya binaen Ezherli âlimler burayı Ebû Nuaym olarak değişmiştir. ${ }^{44}$ İbn Hacer, Muhammed b. Yusuf ifadesinin sadece Kerîme'den nakledilen bir nüshada bulunduğunu ve bazı nüshalarda iki ismin birden geçtiğini belirtmektedir. ${ }^{45}$

- 1453. hadiste (Zekât, 37) geçen musaddık kelimeleri Yûnînî nüshasında mussaddık şeklindedir ve Basrî hem asılda hem de kopyasında bu şekilde olduğunu belirtmiştir. ${ }^{46}$ Ezherli âlimler İbn Hacere ve Kastallânîye atıf yaparak bunu musaddık şeklinde tashih etmiştir. ${ }^{47}$

- 1590. rivayetin (Hac, 45) sonundaki mütâbaat ifadesi Yûnînî nüshasında Yahya 'ani'dDahhâk şeklindedir ki, İbn Hacer’in belirttiğine göre Ebû Zer ve Kerîme nüshalarında böyledir. Hâlbuki burası Yahya b. ed-Dahhâk şeklinde olmalıdır; çünkü bu râvinin adı Yahya b. Abdullah b. ed-Dahhâk'tır. Ezherli âlimler bu şekilde düzeltmiştir. ${ }^{48}$

- Yûnînî nüshasında ve kâle Ebû̀ Harîz 'anişs-Şa'bî... mütâbaatı hem şu an bulunduğu yer olan hadisin sonunda hem de bâb başlı̆̆ının sonunda olmak üzere iki yerde geçmektedir. İlkinde tadbîb işareti ve bir asılda olmadığını gösteren lâ işaretinin bulunduğunu Ezherli âlimler kaydetmiş ve isabetli bir tashihle burayı metinden kaldırmışlardır. ${ }^{49}$

- Yûnînî nüshasında haşiyede belirtilen bir bölümü Ezherli âlimler metne almıştır. Çünkü Yûnînî kendi nüshasında düşen bu kısmın diğer nüshalarda mevcut olduğunu belirtmekte ve bu nüshaları tek tek zikretmektedir. ${ }^{50}$

- Yûnînîde Duâdb. Ebi'l-Furât olarakgeçen isim, yine Basrînnin açılamaları doğrultusunda diğer nüshalara ve İbn Hacer'in Takrîb'ine uyularak Davud şeklinde yazılmıştır. ${ }^{51}$

- 7198. rivayetin (Ahkâm, 42) mütâbaatında geçen Abdullah b. Ebî Cafer isminin doğrusu Ubeydullah b. Ebî Cafer'dir. Basrînin kenardaki izahı doğrultusunda Ezherli âlimler burayı düzeltmiştir. ${ }^{52}$

Âsitâne, II, 5 .

İbn Hacer, Fethu'l-Bârî, II, 302. Bu hadisin tekrarı (1068: Sücûdü'l-Kur’ân, 2) Muhammed b. Yusuf rivayetidir. Bu sebeple 891'in Ebû Nuaym ile başlaması Buhârînin "mümkün olduğunca aynı senedle tekrar etmeme” usûlüne daha uygundur. "Kerîme” nüshası ile “iki şeyhi birden zikreden” nüshanın varlığı ise kanaatimizce Buhârînin 891'de önce 1068'deki senedi aynen tekrarladığını, sonra bunu başka bir şeyhinden de dinlediğini yansıtan senedle değiştirdiğini, ama haşiyede belirtilen bu değişikliği bazı râvilerin iyi yansıtamadığını göstermektedir.

Konya Yusuf Ağa, nr. 5555, vr. 116 ${ }^{\text {b }}$

Âsitâne, II, 116.

Âsitâne, II, 148.

Âsitâne, III, 171.

Âsitâne, IV, 172; Konya Yusuf Ağa, nr. 5555, vr. $296^{\text {b }}$.

Âsitâne, VIII, 127.

Âsitâne, IX, 77. 
- 7241. rivayetin (Temennî, 9) sonundaki Süleyman b. Mugîre mütâbaatı Yûnînî nüshasında 7240’n sonundadır. Basrînin uyarıları ve İbn Hacer'den yaptığı nakiller sebebiyle Ezherli âlimler burayı düzeltmiştir. ${ }^{53}$

- 7350. rivayetin (Ítisâm, 20) senedinde bulunan Süleyman (b. Bilâl) ismi Yûnînî nüshasında yoktur. İbn Hacer’in açıklamaları ve tashihi doğrultusunda Ezherli âlimler bunu eklemiştir. ${ }^{54}$

- 7537. rivayette (Tevhîd, 50) et-Teymî olarak geçen isim Yûnînî nüshasında et-Temîmî şeklindedir. Kastallânînin bunun yanlış olduğuna dair uyarısını dikkate alan Ezherli âlimler burayı düzeltmiştir. ${ }^{55}$

- 7543. hadisin (Tevhîd, 51) sonunda fe-raeytühû yücâniu 'aleyhâ el-hicârete ifadesi geçmektedir. Ezherli âlimlerin belirttiğine göre Yûnînî nüshasında yücâniu yerine yaḥneu kelimesi mevcuttur. Fakat sözlüklerde yaḥneu bu anlamda değildir; ya yücâniu ya da yahnı̂̀ olmalıdır. ${ }^{56}$

Yukarıda kaydettiğimiz tashihlerin tamamı doğrudur; çünkü bunlar Buhârînin değil, Sahîh’i nakleden nüshalardan bazılarının hatasıdır.

\subsection{Mehmed Zihni Efendi}

\subsubsection{Hayatı ve İlmî Kişiliği}

1262/1846 doğumlu Mehmed Zihni Efendi İslâmî ilimlerin hemen her sahasında söz sahibi olabilecek donanıma sahip bir âlimse de özellikle zamanın önde gelen Arapça mütehassıslarından biri olarak tanınmıştır. Galatasaray Mekteb-i Sultânîsi ve Mekteb-i Mülkiyye'de Arapça, fıkıh ve kelam öğretmenliklerinde; Meclis-i Maârif azalıklarında bulunarak Osmanlı ilim ve kültürünün gelişmesine büyük hizmetler etmiş, bilhassa Arapça öğretimi ve fikıh ilmi hususunda büsbütün yeni ve faydalı bir çı̆̆ır açmıştır. ${ }^{57}$ Cumhuriyet döneminden önce yazılmış en derli toplu ilmihal olan Nimet-i İslâm, Meşâhîru'n-nisâ, elMüntehab, el-Muktedab kitapları ile Sahîh-i Buhârî ve Sahîh-i Müslim neşirleri onun en önemli eserleri konumundadır. Zihni Efendi’nin daha çok Arapça ve fikıh alanlarında öne çıktığı halde Sahîhayn’ı tashih ederek İstanbul'da neşreden ilk kişi olması, kanaatimizce onun matbaada musahhih olarak çalışmasıyla elde ettiği dikkat ve tecrübe ile yeni tarz eserler yazmasından anlaşılan yenilikçi ve cesur yönünün birleşiminin sağladığı bir durum olmalıdır.

53 Âsitâne, IX, 85.

54 Âsitâne, IX, 107.

55 Âsitâne, IX, 157.

56 Âsitâne, IX, 158. Hâlbuki bu rivayetin Sahîh’teki tekrarlarından ikisinde yecneu ifadesi vardır. Buna göre yucâniu yerine, yahneu ile yazımı aynı olan ve sadece bir noktası unutulan yecneu kelimesiyle tashih edilmesi daha uygundur. 
Olgun bir kişiliğe ve güzel bir ahlâka sahip olduğu belirtilen Zihni Efendi’yle ilgili kaydedilen şu bilgi onun bu yönünü gösterir: Bulunduğu bir mecliste dönemin iyi yazarlarının sayıldığı bir gazete yazısı gündeme gelince Zihni Efendi bu listede Mustafa Sabri’nin (ö. 1954) de bulunması gerektiğini belirtir. Kendisine "ama o sizi de tenkit ediyor" denildiğinde ise şu cevabı vermiştir: "Beni de tenkit etse o genç iyi yazıyor!" 58

\subsubsection{Sahîh-i Buhârî Baskısı}

Zihni Efendi daha önce belirttiğimiz gibi Sahîh-i Buhârînin İstanbul'daki ilk basımını yapan kişidir. İki yıllık bir çalışma sonrasında Matbaa-i Âmire diye bilinen Dârü’t-Tibấa elÂmire'de 1315/1898 yılında yapılan bu neşrin çoğunlukla Kastallânî şerhine uygun olarak yapıldığı, kitabın başındaki notta belirtilmektedir. Kitabın en sonunda da Mısır'da basılan iki metinle karşılaştırılarak tashih yapıldığı Mehmed Zihni Efendi tarafından açıklanmakta ve Mısırlı musahhihlere teşekkür edilmektedir. ${ }^{59}$ Zihni Efendi tashihlerin bir kısmını da Aynînin şerhine göre yapmıştır ki, ileride bazı örneklerini göreceğimiz gibi bunlara ayrıca işaret etmiştir.

Zihni Efendi’nin çalışmasında "sadece tashihle iktifa edilmemiş; metinler üzerine doğru okuyup anlamayı kolaylaştıracak harekeler konularak sayfa kenarlarına bazı açıklayııı notlar ilave edilmiştir. Bu notlarda kelimelerin sarf ve lügat yönünden açıklaması, hadisin başka bir rivayetinde veya Sahîh-i Buhârînnin başka nüshalarında bulunan lafız fazlalığı, eksikliği veya lafız farkı, lafız üzerinde bulunan harekelerin değişik ihtimalleri gibi hususlara da yer verilmiş, gerektiğinde şerhlerine bakılması istenmiştir." ${ }^{60}$ Mehmed Zihni’nin bu neşri aynen basılmış, eklenen bâb numaraları ve fihristle kitap daha kullanışlı hale gelmiştir. ${ }^{61}$ Çalışmamızda eserin bu baskısı kullanılmıştır.

\subsection{Zihni Efendi’nin Tashihlerinin Değerlendirilmesi}

Öncelikle Mehmed Zihni Efendi’nin Yûnînî nüshasını basarken yapmış olduğu tashihlerin nasıl tespit edildiği hususunda birtakım bilgilerin verilmesi uygun olacaktır. Buhârînnin el-Câmi'u's-sahîh'inin okunması esnasında, eserdeki bazı isim ve ifadelerde hataların olduğu görülmüş, Sahîh nüshaları ve şerhlerine gidildiğinde ise hatanın bazı nüshalardan kaynaklandığı ve bu haliyle mevcut neşirlere de yansıdığı anlaşılmıştır. Tespit ettiğimiz ve hatalı olduğunu düşündüğümüz yüzden fazla maddede Zihni Efendi’nin neşri incelenmiş ve onun bazı yerleri tashih ettiği, bazı tashihlerinin isabetli olmadığı, bazı yerleri ise gözden kaçırdığı fark edilmiştir. Tespit edilebilen doğru tashihler, hadis numaralarını

Ermiş, Mehmed Zihni Efendi, s. 262.

Sahîhu'l-Buhârî (haz. Mehmed Zihni Efendi), I, 1, VIII, 219. Kitabın orijinal baskısı İSAM Kütüphanesi’nde mevcuttur.

Ermiş, Mehmed Zihni Efendi, s. 124.

Sahîhu'l-Buhârî (İstanbul: Çağrı Yayınları, 1992). 
aldığımız baskıda ${ }^{62}$ - ve diğer birçok baskıda - tashih edilmemiş olarak mevcuttur; çünkü Yûnînî nüshasında bu şekilde geçmektedir. Hadisleri numaralandırma gibi birçok artısı olan bu baskıda ve Yûnînînin ana metnini aynen basan diğer baskılarda, yıllarca önce yapılmış olan tashihlerin bile olmayışı bu baskılar için bir kusur olduğu gibi Zihni Efendi için önemli bir fazilettir.

\subsection{1. İsabetli Tashihleri}

- 137. hadisin (Vudû̀, 4) senedi 'ani'z-Zührî 'an Sa'îd b. el-Müseyyeb 'an 'Abbâd șeklindedir. Burası ve 'an 'Abbâd şeklinde olmalıdır. Yani bu hadisi Sa'îd, Abbâd'dan nakletmemiş; bilakis Zührî hem Sa îd’den hem de Abbâd b. Temîm’den nakletmiştir.

İbnüll-Müseyyeb'in Abbâd'dan rivayeti olmadığ gibi $^{63}$ hadisin iki tekrarında da Zührî̀den sonra sadece Abbâd ismi vardır. ${ }^{64}$ Çünkü Süfyan’ın bazı râvileri bunu 'an Sa'îd $b$. el-Müseyyeb ve 'an 'Abbâd şeklinde aktarırken bazıları sadece 'an 'Abbâd diyerek nakletmiştir. Mehmed Zihni Efendi burayı tashih ederek nakletmiştir. ${ }^{65}$

- 253. hadisin (Gusl, 3) sonunda Buhârînin şu ifadesi nakledilmektedir: ve kâle Yezîd b. Harun ve Behz ve'l-Cüddî 'an Şu'be kadre sầin.

$\mathrm{Bu}$ ifadeler 251. hadis olan Şu'be rivayetiyle alakalıdır ve orada zaten geçer. Bu tekrarın bir göz kayması sonucu oluştuğu ve sonradan bu yanlışın düzeltilmediği çok açıtır. 253’ten sonraki bu ifadeler kaldırılıp yerine şu açıklama konulmalıdır: Kâle Ebû 'Abdillâh: Kâne İbnu 'Uyeyne yekûlu ahîren 'ani'bni 'Abbâs 'an Meymûne, Ves'sahîhu mâ revâhu Ebû Nuaym. Çünkü Yûnînînin kenarda belirttiği diğer nüshalarda sadece bu açıklama vardır. ${ }^{66}$

Yûnînînin en muteber kopyasını yazan Abdullah b. Sâlim el-Basrî mevcut durumun Yûnînînin aslından kaynaklandığını, Mekkî kopyasında bunun düzeltildiğini açıklar. ${ }^{67}$ Mehmet Zihni Efendi burada doğru bir tashihte bulunarak sadece olması gereken izahı nakletmiştir; çünkü onun dikkate aldığı Kastallânî şerhinde sadece bu vardır ve farklı bir nüsha kaydı bulunmamaktadır. ${ }^{68}$

- 292. hadisin (Gusl, 29) sonu şöyle bitmektedir: Kâle Yahyâ ve ahberanî Ebû Seleme enne 'Urve b. ez-Zübeyr ahberehû ennehû semia zâlike min Rasûli'llâh. Ayrıca 291'de vecebe'lgaslu, 293’ün sonunda da el-gaslü ahvat ifadeleri geçmektedir.

62 Sahîhu'l-Buhârî (Beyrut: Dâru'l-Erkam, ts.).

63 İbn Hacer, Fethu'l-Bârî, I, 191-2.

64 Buhârî, Vudû', 34 (177); Buyû́, 5 (2056).

65 Çağrı, I, 43.

66 Âsitâne, I, 60.

67 Basrî, Dıyâü's-sârî, IV, 158-9.

68 Çağrı, I, 68; Kastallânî, İrşâd, I, 318. 
Urve b. ez-Zübeyr isminden sonra olması gereken ahberehû enne Ebâ Eyŷ̂b ahbereh $\hat{u}$ kısmı yanlışlıkla düşmüştür. Bu cümlenin eklenmesi gerekir; çünkü Urve tâbiîn neslinden olduğundan onun Hz. Peygamber'den hadis işitmesi mümkün değildir. Yûnînînin belirttiğine göre düşen bu kısım birçok nüshada mevcuttur. ${ }^{69}$ Diğer yandan iki yerde geçen gasl ifadesi gusl olmalıdır; çünkü bu iki yerde yıkamadan değil, yıkanmadan bahsedilmektedir. Mehmed Zihni düşen kısmı eklediği gibi iki kelimeyi de el-guslü şeklinde harekelemiştir; çünkü Kastallânî bu senedi tam olarak nakleder ve iki kelimeyi de gusl olarak belirtir. ${ }^{70}$

- 313. hadisin (Hayd, 12) senedi şu şekildedir: ... 'an Eyyûb 'an Hafsa - kâle Ebû 'Abdillâh: ev Hişâm b. Hassân 'an Hafsa 'an Ümmi Atıyye 'ani’n-Nebî - kâlet: Künnâ nünhâ...

Rivayetin sonunda da kâle ravâhu Hişâm b. Hassân 'an Hafsa 'an Ümmi 'Atryye 'ani’nNebî ifadesi vardır. ${ }^{71}$

Baş kısımda bulunan ve Buhârî̀ye (Ebû Abdullah) atfedilen ev Hişâm... 'anin'n-Nebî ifadesiyle ne anlatılmak istendiği tam anlaşılamamaktadır. Çünkü metnin başında kâlet kelimesinin bulunması bir yana ve künnâ nünhâ şeklinde başlayan bir rivayetin senedinin 'anin-Neb̂̀ ifadesiyle bitmesi mümkün değildir. Burada diğer bir râvinin farklı nakli belirtilmek istendiği anlaşılmaktadır ancak bu farklı nakil en sonda zaten kayıtlıdır.

Diğer yandan bu fazlalık kısım ile hadisin sonunda bulunan mütâbaatı beraber nakleden sadece Kerîme nüshasıdır; diğerlerinde kâle Ebô 'Abdillâh... 'anin-Nebî kısmı yoktur. Kastallânî baştaki fazlalığı metin olarak kaydetmeyip sadece belirtmiş, buna uygun olarak Zihni Efendi bu ifadeyi kaldırmıştır. ${ }^{72}$

- 643. hadisin (Ezân, 28) sonunda şu cümle vardır: Ve kâle’l-Hasen... lem yuṭi hâ.

$\mathrm{Bu}$ cümle bir sonraki bâbın başlığından sonra aynen nakledilmektedir ve ilgili olduğu yer de orasıdır. 643’ten sonra verilmesinin bir yanlışılı sonucu olduğu açıktır; nitekim birçok nüshada bu kısım yoktur. ${ }^{73}$ Zihni Efendi doğru bir tashihle burayı kaldırmıştır; çünkü Kastallânî burayı metin olarak nakletmez ve sadece bir nüshada bulunduğunu belirttiği bu fazlalığın bir sonraki bâbda zaten geçtiğini, asıl yerinin de orası olduğunu söyler. ${ }^{74}$

- 854. hadisin (Ezân, 160) sonundaki açıklamalar şu şekildedir: Ve kâle Mahled b. Yezîd 'ani'bni Cüreyc: "illâ netnehû." Ve kâle Ahmed b. Sâlih 'ani'bni Vehb: "Utiye bibedr - Kâle İbn Vehb: ya'nî țabakan - fîhi hudarât." Ve lem yezkur el-Leys ve Ebû Safvân 'an Yûnus kıssate'l-kıdr; felâ edrî hüve min kavliz-Zührî ev fi'l-hadîs.

\footnotetext{
Âsitâne, I, 66.

Çağrı, I, 76; Kastallânî, İrşâd, I, 339.

Âsitâne, I, 69.

Kastallânî, İrşâd, I, 352; Çağrı, I, 80.

Âsitâne, I, 131.

Çağrı, I, 158; Kastallânî, İrşâd, II, 24.
} 
855'inci hadisin sonunda da şu açıklama mevcuttur: Ve kâle Ahmed b. Sâlih ba'de hadisi Yûnus 'ani'bni Şihâb ve hüve yüs bitu kavle Yûnus.

Sadece ve kâle Mahled b. Yezîd 'an İbni Cüreyc: illâ netnehû açıklaması 854. hadisle ilgilidir. $\mathrm{Bu}$ cümleden sonraki ve kâle Ahmed $b$. Sâlih 'ani'bni Vehb diye başlayan açıklamalar asıl yerine, yani 855 . hadisin sonuna alınmalıdır. 855 'in sonunda bulunan ve daha sonrakilerin bir yorumuna benzemekle beraber ne anlama geldiği tam anlaşılamayan son cümle ise başka bir nüshada olmadığından kaldırılmalıdır.

Yûnînînin belirttiğine göre bu açlklamalar Ebû Zer, Asîlî, İbn Asâkir ve Semânî nüshalarında 855. hadisin sonundadır ve bu nüshalarda en sondaki açıklama (Ve kâle Ahmed b. Sâlih ba'de hadisi Yûnus...) da yoktur. ${ }^{75}$ Mehmed Zihni ilgili kısmı 855 'in sonuna almış ve en sondaki açıklamayı tamamen kaldırmıştır; çünkü Kastallânî bu kısmı doğru yerde nakleder, en sondaki açıklamayı ise metin dışı olarak belirtir. ${ }^{76}$

- Ezân bölümünün 163. bâb başlığı şu şekildedir: Bâbu intızâri'n-nâsi klyâme'l-imâmi'lâlim.

Bu bâb başlığının tamamen kaldırılması gereklidir.

162. bâb kadınların gece ve sabah karanlığında camiye çıkmasıyla ilgili bir başlık taşımaktadır: Bâbu huurûcin-nisâi... Buradaki iki hadis $(864,865)$ bu konuyla ilgili olduğu gibi, bahsetmekte olduğumuz 163. bâb başlı̆̆ından sonra gelen dört hadis de aynı konuyla ilgilidir. Evet, söz konusu başlıktan sonraki hadiste (866) bu başlıkta belirtilen konu da vardır; ama ondan sonraki üç hadisin bu konuyla hiçbir ilgisi bulunmaz. İbn Hacer'in naklettiğine göre sadece Kerîme nüshasında bulunan bu bâb başlı̆g 177 İbn Asâkir, Ebû Zer ve Asîlî nüshalarında yoktur. ${ }^{78}$ Mehmed Zihni bu bâb başlığını kaldırmıştır; çünkü Kastallânî metin dışı olarak kaydettiği bu bâb başlığının buraya uygun olmadığını söylemektedir. ${ }^{79}$ Buhârînnin bâb başlıklarına tahsis edilmiş İbnüll-Müneyyir (ö. 683/1284) ve Şah Veliyyullah (ö. 1176/1762) gibi âlimlerin eserlerinde bu bâba yer verilmez. Çünkü İbnü'l-Müneyyir, Asîlî nüshasını kullanır ve bu kısmın o nüshada olmadığı yoktur. Şah Veliyyullah’n kaynağı ise İbn Hacer'dir.

- 874 ve 875. hadisler (Ezân, 164) ve bunların bulunduğu bâbın başlığı.

Bu bâbın tamamı, yani bâb başlığı ve iki hadisi Sahîh'in yeni baskılarından çıkarılmalıdır; çünkü bu bâbın biraz öncesinde hem bâb başlığı hem de hadisler aynen mevcuttur. ${ }^{80}$

Âsitâne, I, 170-1.

Çağri, I, 207-8; Kastallânî, İrşâd, II, 147.

İbn Hacer, Fethu'l-Bârî̀, II, 280.

Âsitâne, I, 172.

Çağrı, I, 210 (bu baskıda diğerleriyle uyum için 162. bâbdan sonra 164. bâba geçilmiş; fakat 163. bâbın niye atlanıldığına dair hiçbir açıklama yapılmamıştır); Kastallânî, İrşâd, II, 152.

870. ve 871. hadisler ve aynı ifadeleri içeren bâb başlı̆̆ı. 
Buhârînin hadisleri tekrarlama usûlünde bir bâbı hem de bir sayfa arayla aynen tekrar etme yoktur.

Ebû Zer nüshasında bu tekrar yoktur ${ }^{81}$ ve İbn Hacer bu fazlalığı içeren nüshadan hiç bahsetmemektedir. ${ }^{82}$ Zihni Efendi doğru bir tashihle bu fazlalık kısmı kaldırmıştır. ${ }^{83}$

- 1048. hadisten önceki başlıkta (Küsûf, 6) Bâbu kavlin-Nebî: Yuhavvifu'llâhu 'ibâdeĥ̂

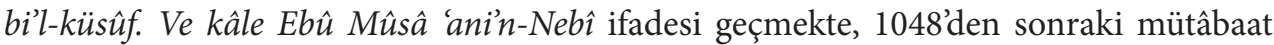
ifadelerinin en sonunda tâbe'ahû Eşás 'ani'l-Hasen denilmektedir.

Bu haliyle Ebû Musảnın naklettiği rivayet kısmı atlanmış gibi durmaktadır; hâlbuki onun rivayeti başlıkta zaten belirtilmiştir. Bu sebeple burası, Yûnînînin belirttiği diğer nüshalarda olduğu gibi ${ }^{84}$ kâleĥे Ebû Mûsâ şeklinde kaydedilmelidir.

Mütâbaat ifadelerinde ise sıralamada bir hata yapılmıştır. Çünkü Buhârî burada, başlıkta kullandığ 1 ifadeyi nakletmeyenleri belirtmektedir; en son kısım ise bunu nakledenlerle ilgilidir. İbn Hacer'in kaynaklardan naklettiği üzere Eşas bu cümleyi aktarmaz ve bu sebeple söz konusu ifade ilk cümleden sonraya alınmalıdır. Onun belirttiğine göre bu kısmı en sonda zikreden sadece Kerîme'dir. ${ }^{85}$ Zihni Efendi iki yeri de tashih etmiştir; çünkü Kastallânî metin olarak diğer nüshalarda yazanı nakletmiş, Yûnînî nüshasındaki ana metni ise sadece belirtmiştir. ${ }^{86}$

- 1071. hadisten önceki Sücûdü'l-Müslimîn meá'l-müşrikîn bâbında (Sücûdü'l-Kurân, 5) ve kâne İbn 'Umer yescüdü 'alâ vuḍ̂in ibaresi bulunmaktadır.

İbn Hacer çoğunluğun burayı 'alâ gayri vuḍ̂in şeklinde naklettiğini ve doğrusunun da bu olduğunu, çünkü İbn Ömer ve Şa bî̉nin bu görüşte olduğunun kaynaklarda geçtiğini belirtmektedir. ${ }^{87}$ Zihni Efendi’nin tashihi bu şekilde olmuştur; çünkü Kastallânî gayr kelimesini metinde nakletmiş ve bunun bulunmasının daha doğru olduğunu söylemiştir. ${ }^{88}$

- 1172. hadisin (Teheccüd, 29) sonunda zikredilen mütâbaat ifadeleri 1173'ün sonunda sıralaması değiştirilerek tekrarlanmaktadır. 1172: ...kâle İbn Ebi'z-Zinâd... tâbéah $\hat{u}$ Kesîr b. Ferkad... 1173: ...tâbe'ahû Kesîr b. Ferkad... ve kâle İbn Eb'z-Zinâd... Hâlbuki burada tek bir hadis rivayeti vardır ${ }^{89}$ ve bu rivayetle ilgili mütâbaat bilgilerini içeren ifadeler gereksiz yere tekrar edilmektedir.

81 Âsitâne, I, 173-4.

82 İbn Hacer, Fethu'l-Bârî, II, 280-1

83 Çağrı, I, 211.

84 Âsitâne, II, 36.

85 İbn Hacer, Fethu'l-Bârî, II, 430.

86 Çağrn, II, 26; Kastallânî, İrşâd, II, 268.

87 İbn Hacer, Fethu'l-Bârî, II, 443. Yûnînî ise elindeki nüshalardan sadece Ebû Zer’in böyle naklettiğini söyler (Âsitâne, II, 41).

88 Çağrn, II, 32; Kastallânî, İrşâd, II, 283.

89 İki numara verilmesinin sebebi, İbn Ömer’in rivayetin ilk kısmını doğrudan naklederken ikinci kısmını ablasından 
Zihni Efendi bunlardan sadece birini kaydederek doğru bir tashihte bulunmuştur. ${ }^{90}$ Fakat burada farklı bir ifadesi nakledilen İbn Ebìz-Zinâd'ın rivayeti sona alınsaydı daha güzel olurdu ki, Yûnînînin ana metninde en sonda bulunan mütâbaat ifadeleri aynen bu şekildedir. ${ }^{91}$

- 1334. hadisin (Cenâiz, 64) sonundaki mütâbaat ifadeleri ve kâle Yezîd b. Harun ve Abdüssamed 'an Selìm: Ashame. Ve tâbéahû 'Abdüssamed şeklindedir. Sondaki Abdüssamed mütâbaatı bir önceki cümlede zaten zikredilmiștir; bu haliyle anlamsız bir tekrar oluşturmaktadır. ${ }^{92}$ Zihni Efendi son kısmı kaldırarak bu hatayı tashih etmiştir; çünkü Kastallânî metni böyle nakletmiş, Yûnînî nüshasındaki durumdan hiç bahsetmemiştir. ${ }^{93}$

- 1458. hadiste (Zekât, 41) enne'llâhe ferada 'aleyhim zekâten min emvâlihim ve türaddü 'alâ fukarâihim ifadesinin aslında zekâten tü'hazu min emvâlihim şeklinde olması gerektiği açıktır. Bulak baskısını yapan Ezherli âlimler bu kelimenin Kastallânî̉de mevcut olduğuna işaret etmekle yetinmiş, Zihni Efendi ise bu kelimeyi eklemiştir. ${ }^{94}$

- Buyû́ bölümündeki 95. bâbın ${ }^{95}$ başlı̆̆ında yapılan nakiller içerisinde sünnetukum beynekum ribhan ifadesi geçmektedir.

Ebû Zer nüshasında olmayan ${ }^{96}$ ribhan kelimesinin burada bir anlamı yoktur. Hemen altına denk gelebilecek bir yerde geçen ve orada bir anlamı olan ribhan kelimesi muhtemelen göz kayması sonucu buraya da yazılmıştır. Zihni Efendi bu kelimeyi kaldırmıştır; çünkü Kastallânî bazı nüshalarda geçen bu kelimenin burada bulunmasının yanlış olduğunu söylemektedir. ${ }^{97}$

- 2620. hadiste (Hibe, 29) Hz. Esmâ' bt. Ebî Bekr'in ifadesi kultu: ve’hye (ve hiye) râgibe, e-feasılu ümmî? şeklinde baş kısmı eksik olarak geçmektedir. Kastallânî burayı inne ümmî kadimet ve'hye râgibe... olarak naklettiğinden ${ }^{98}$ Zihni Efendi de bu şekilde neşretmiştir. ${ }^{99}$

nakletmesidir. Tekrarları gösterirken büyük bir kolaylık sağlayan bu uygulama, hadislerin toplam sayısını şişirmekte ve bu örnekteki gibi bazı karışık yerlerde yanlışın devam etmesine sebep olmaktadır.

90 Çă̆rı, II, 53.

91 Âsitâne, II, 57.

92 Büyük bir ihtimalle bunun sebebi, Müstemlînin ve kâle Yezîd b. Harun 'an Selîm: Ashame. Ve tâbéahû 'Abdüssamed şeklindeki nüshası ile diğerlerinin ve kâle Yezîd b. Harun ve 'Abdüssamed 'an Selìm: Ashame şeklindeki nüshasının (İbn Hacer, Fethu'l-Bârî, III, 158) Kerîme tarafindan birleştirilmek istenmesidir.

93 Çağrı, II, 91; Kastallânî, İrşâd, II, 431. Aslında buradaki sorun tam olarak çözülmemiştir; çünkü bu tashih sonrasında bile metinde bulunan isim ile mütâbaatta geçen isim aynıdır. Yani mütâbaatın neden zikredildiği anlaşılmamaktadır. Fakat elimizdeki nüshaların çoğu bu şekilde olduğundan buradaki sorunu çözmek kolay değildir. Bu sorun başka bir incelememizde çözülmeye çalışılmıştır.

94 Âsitâne, II, 119; Çağrı, II, 125.

95 Bâbu men ecrâ emra'l-emsâri...

96 Âsitâne, III, 79.

97 Çağrn, III, 36; Kastallânî, İrşâd, IV, 96.

98 Âsitâne, III, 164. Ezherli âlimler Kastallânî șerhinde bu kısmın olduğunu kenarda belirtmişlerdir.

99 Çă̆rı, III, 142. 
- 3608 ve 3609’uncu hadislerde (Menâkıb, 25; 34 ve 35. hadisler) “fityân/gençler" kelimesi geçmektedir.

$\mathrm{Bu}$ kelime yanlış yazılmıştır. Doğrusu "fietâni/iki grup" şeklindedir. 100 "Gençler savaşacak" ifadesinin burada bulunması pek anlamlı değildir. "İki grup savaşacak" ise doğru anlatımdır ve devamında gelen "ikisinin davası birdir" cümlesine uygun olan da budur. Mehmed Zihni Efendi, Kastallânî nüshasında fityân şeklinde geçtiğini ve bunun bir tashîf olduğunu belirterek Aynî şerhindeki fietâni lafzını tercih etmiştir. ${ }^{101}$ Yûnînîde fityân yazılmasına rağmen kenarda bu kelimeyle ilgili olarak "hamişte fietâni olarak düzeltilmiştir" kaydı mevcuttur. ${ }^{102}$

- 3720. hadis (Fezâilü ashâbi’n-Nebî, 13) haddesenâ Ahmed b. Muhammed ahberenâ Hişâm b. 'Urve şeklinde başlamaktadır. Bu iki isim arasında ahberenâ 'Abdullâh (b. Mübârek) kısmı Yûnînîde düşmüştür. ${ }^{103}$ Ebû Zer nüshasında mevcut olan bu isim burada muhakkak olmalıdır; çünkü Ahmed el-Mervezînin (ö. 235/850) Hişâm’dan (ö. 146/7634) rivayeti yoktur ve onun Sahîh'teki diğer on sekiz rivayeti de İbnü'l-Mübârek'tendir. Kastallânîşerhinde Abdullah kısmı mevcut olduğundan Zihni Efendi bunu eklemiştir. ${ }^{104}$

- 4689'un (Tefsîr, Yusuf, 2) senedindeki isim Yûnînînin metninde Abdullah olarak geçmektedir. ${ }^{105} \mathrm{Bu}$ ismin doğrusu Ubeydullah'tır. Nitekim bu sened 3383'ün (Ehâdîsu'lenbiyâ, 19) sonunda tekrarlanmaktadır ve orada Ubeydullah şeklindedir. Ebû Zer haricindeki nüshalarda Abdullah şeklinde geçtiğini belirten Kastallânî bunu Ubeydullah olarak nakletmiş, Zihni Efendi de bu şekilde tashih etmiştir. ${ }^{106}$

- 6057. hadisin (Edeb, 51) senedinde haddesenâ İbn Ebî Zi'b 'ani'l-Makburî 'an Ebî Hüreyre şeklinde geçen kısımda Saî̀ el-Makburî ile Ebû Hüreyre arasında bulunan 'an ebîhi ifadesi düşmüştür. Ebû Zer nüshasında ${ }^{107}$ ve İbn Ebî Zi’b’in Sahîh'teki diğer tarikinde 108 bu kısım mevcuttur. Zihni Efendi 'an ebîhi ifadesini eklemiştir; çünkü Kastallânî bu ifadeyi şerhinde zikretmiş ve kullandığı Yûnînî kopyasında bu kısmın bulunduğunu belirtmiştir. ${ }^{109}$ Buradaki hatanın Buhârîye ait olma ihtimali de vardır; ancak bu rivayetin aslında 'an ebîhi kısmı mevcut olduğundan Ebû Zer nüshasındaki gibi 'an ebîhi lafzıyla kaydedilmesi gerekmektedir.

- 7095. hadis (Fiten, 16) Haddesenâ İshak el-Vâsıtî, haddesenâ Halefşeklinde başlamaktadır.

100 Fityân ile fietân kelimelerinin noktasız yazılıı̧ı aynıdır.

101 Çağrrı, IV, 178.

102 Âsitâne, IV, 200.

103 Âsitâne, V, 21.

104 Kastallânî, İrşâd, VI, 122; Çağrı, IV, 211.

105 Âsitâne, VI, 76 (Ebû Zer nüshasında Ubeydullah şeklinde olduğu hamişte belirtilir).

106 Kastallânî, İrşâd, VII, 177; Çağrı, V, 216.

107 Âsitâne, VIII, 17

108 1903: Savm, 8.

109 Çağrı, VII, 87; Kastallânî, İrşâd, IX, 44. Kastallânî, Yûnînî nüshasının Mizzî kopyasını kullanmıştır. 
Buradaki isim Halef değil, Hâlid olmalıdır. Anlaşılan o ki, Hâlid isminin elifsiz yazılışı ile Halef isminin yazılışı çok yakın olduğundan isimler karıştırılmıştır. Yanlışlığın kaynağı olan Yûnînî nüshasında bu isim Halef olarak geçse de kenarda şu açıklama vardır: Ebû Zer, Asîlî, İbn Asâkir ve Semânî nüshalarında Hâlid şeklindedir. ${ }^{110}$ Kastallânî bu ismi Hâlid olarak naklettiğinden Zihni Efendi de bu şekilde düzeltmiştir. ${ }^{111}$

- 7416. hadisten (Tevhîd, 20) önce ve kâle 'Ubeydullâh b. 'Amr 'an 'Abdilmelik: Lâ şahsa ăgyeru mine’llâhi ifadesi mevcuttur.

Bu cümle 7416. hadisin mütâbaatıdır; bu sebeple ondan sonraya alınmalıdır. ${ }^{112}$ Ebû Zer nüshasında doğru yerde olan bu cümleyi Kastallânî de hadisten sonra kaydetmiş, Zihni Efendi’nin tashihi de bu şekilde olmuştur. ${ }^{113}$

Mehmed Zihni Efendinin tashih yapmayıp kenarda uyarıla yetindiği yerler de mevcuttur. Mesela 2646. hadiste (Şehâdât, 7) göz kayması sonucu tekrarlanan ve anlam düşüklügüne sebep olan bir cümleyle ilgili kenarda uyarı yapmakla yetinmiştir. ${ }^{114} \mathrm{Zihni}$ Efendi’nin kimi zaman Kastallânî metni yerine Yûnînînin ana metnindekini tercih ettiği de vakidir. Mesela 4742. hadiste (Tefsîr, Hac suresi, 2) Buhârînin şeyhi İbrahim b. el-Hâris olarak geçer. Zihni Efendi, Yûnînî metnindeki sahih nüshalarda ${ }^{115}$ ve Aynî şerhinde böyle olduğunu ancak Kastallânî şerhinde İbrahim b. Münzir olarak geçtiğini belirtir. ${ }^{116}$

\subsubsection{Eksik ve Yanlış Tashihleri}

- Îmân bölümünün ikinci bâbı Bâbu duâukum îmânukum olarak geçer.

Mehmed Zihni Efendi doğru bir tashihle buradaki bâb kelimesini kaldırmış ve böylece, sonrasındaki ifadeyi öncekilerin bir devamı yapmıştır. ${ }^{117}$ Çünkü bâb başlığı olarak kaydedilen bu ifadeden sonra gelen hadis, birinci bâbın başlığında belirtilen hadistir ve duâukum îmânukum ifadesiyle bir ilgisi yoktur. Bâb kelimesi Ebû Zer nüshasinda mevcut olsa da Kirmânî (ö. 787/1385) bizzat Firebrîye dinletilen ve üzerinde onun yazısı bulunan

110 Âsitâne, IX, 54.

111 Kastallânî, İrşâd, X, 189; Çağrı, VIII, 95.

112 İbn Hacer, Fethu'l-Bârî, XIII, 341.

113 Âsitâne, IX, 123; Kastallânî, İrşâd, X, 389; Çağrı, VIII, 174.

114 Çağrı, III, 149.

115 Mehmed Zihni’nin "nüshalar" ifadesi Yûnînî nüshasındaki diğer dört nüshayı da içermesi içindir. Çünkü Yûnînînin herhangi bir nüsha farklıllı̆̆na işaret etmemesi diğerlerinde de bu şekilde olduğunu göstermektedir.

116 Çağrı, V, 242. Zihni Efendi’nin tercihi doğrudur. İbn Hacer, İbrahim b. el-Hâris’in naklettiği 2739. rivayeti (Vasâyâ, 1) onun Sahîh'teki tek rivayeti olarak belirtmişse de (Fethu'l-Bârî, V, 276) bu yanlıştır. Çünkü konumuz olan rivayet, 2739'da olduğu gibi Yahya b. Ebî Bükeyr'den nakledilir. Her ikisini de İbrahim b. el-Hâris'in aktardığı açıktır. Nitekim Mizzî de Yûnînî gibi kaydeder (Tuhfetü'l-eşrâf bi-márifeti'l-etrâf me'a en-Nüketi'z-zurâf li'bn Hacer [nşr. Şeyh Abdürrezzâk el-Mehdî], I-XII, Beyrut: Dâru'l-Kitâbi'l-Arabî, 2008, IV, 305 [5556]). Zihni Efendi’nin belirttiği gibi Aynînin şerhinde de İbrahim ismi geçer (bk. Umdetü'l-kârî fî șerhi Sahîhi'l-Buhârî, I-XX, Mısır: Mektebetü Mustafa el-Bâbî, 1972, XV, 322).

117 Çağrı, I, 8 (fakat tıpkıbasımı yapanlar buraya bâb numarası vermiştir). 
bir nüshada bu bâb ifadesinin geçmediğini nakleder. Bu nüshayı dikkate alan İbn Hacer hemen öncesindeki nakiller gibi bu ifadenin de İbn Abbâs'tan nakledildiğini açıklamıştır. ${ }^{118}$

Yûnînînin hamişte belirttiğine göre Ebû Zer nüshasında bu kısımdan sonra şu açıllama vardır: likavlihî teâlâ: Kul mâ ya'beu bikum Rabbî levlâ du'âukum. Ve ma'na'd-du'âi fi'l-lugati el-îmânu. ${ }^{119}$ Mehmed Zihni bu kısmı ana metne dâhil etmiştir. Hâlbuki bu açıklama sadece Yûnînînnin elindeki Ebû Zer nüshasında geçer. Nitekim şerhlerinde Ebû Zer nüshasını esas alan İbn Hacer ile Kirmânî bu kısma hiçbir şekilde değinmemiş, Aynî ise bunun Sahîh'te bulunduğu iddiasını garipsemiştir. ${ }^{120}$

Diğer yandan bu açıklamada bir gariplik vardır. Çünkü duanın sözlükte iman anlamına gelmesi mümkün değildir. Bu anlam hiçbir sözlükte bulunmadığı gibi herhangi bir dilcinin bu yönde bir açılklaması da bilinmemektedir. Buna ek olarak cümlenin kendi içinde bir çelişki de mevcuttur. Çünkü cümlenin ilk kısmında geçen izah dikkate alındığında son kısım olumsuz (ve mâ máne'd-duâi...) olmalıdır. Şayet son kısım olumsuz olsaydı çelişki kalkar ve bu durumda anlatılmak istenen şey şu olurdu: "İbn Abbas'in duâukum îmânukum ifadesi, Furkan Sûresinin son ayetinde bulunan du'âukum kelimesinin tefsiridir, yoksa sözlüklerdeki anlamı bu değildir."

Bütün bunlar dikkate alındığında buradaki tam tashihin şu şekilde olması gerekmektedir: Bâb lafzıyla beraber sadece bazı Ebû Zer nüshalarında bulunan son kısım da kaldırılmalı, du'âukum îmânukum ifadesinden sonra doğrudan hadis nakline geçilmelidir.

- Kitâbü'l-İlm bölümünün 6. bâbı şu şekildedir: Bâbu mâ câe fi'l-'ilm ve kavlihî teâlâ "Ve kul Rabbi zidnî 'ilmen”' [Tâhâ 114]. el-Kirâetu ve'l-ardu 'ale’l-muhaddis. Ve reâ... ${ }^{121}$

Burada Bâbu mâ câe fi'l-'ilm ve kavlihî teâlâ "Ve kul Rabbi zidnî 'ilmen" "kısmı kaldırılmalı ve bu bâb şu şekilde olmalıdır: Bâbu'l-kırâeti ve’l-ardı 'ale’l-muhaddis. Ve reâ...

Kaldırılması gerektiğini söylediğimiz kısım Ebû Zer (ö. 434/1043), Asîlî (ö. 392/1002), İbn Asâkir (ö. 571/1175-76) ve Semânî (ö. 562/1167) nüshalarında mevcut değildir. ${ }^{122}$

Buhârîbu başlıktan sonraki açıklama kısmında sadece kıraat ve arzkonusuna değinmekte, daha sonra hadis olarak bir tek Dımâm b. Sa'lebe rivayetini aktarmaktadır ki, bunun kıraat ve arzla alakasını zaten kendisi belirtmiştir. Bunların iki ayrı bâb olması ve Buhârînnin kimi yerde yaptığı gibi ilk bâbda hiçbir hadis bulunmaması da bir ihtimaldir. Nitekim Mehmed Zihni Efendi böyle tashih etmiştir. ${ }^{123}$ Ancak Yûnînîde bile bu böyle değildir ve bu ilk bâbı destekleyecek ikinci bir kaynak yoktur.

118 İbn Hacer, Fethu'l-Bârî, I, 42.

119 Âsitâne, I, 11.

120 İbn Hacer, Fethu'l-Bârî, ay; Aynî, Umde, I, 75-6.

121 Sahîhu'l-Buhârî, Dâru'l-Erkam, s. 29.

122 Âsitâne, I, 22; Kastallânî, İrşâd, I, 158; İbn Hacer, Fethu’l-Bârî, I, 121.

123 Çağrı, I, 22 (baskıyı yapanlar, diğerleriyle uyumu bozmamak için ilk bâba numara vermemiştir). 
Zihni Efendi’nin buradaki diğer bir yanlışı, daha sonraki izahlarda yaptığı tekrarlamalardır. ${ }^{124} \mathrm{Bu}$ hatanın sebebi, Yûnînînin kenarda naklettiği ve gerçekten çok karışık olan bütün haşiyelerin metne alınmak istemesidir. Hâlbuki bu haşiyelerin 'farklı zamanlarda farklı ifadelerle aynı şeyin vurgulandığı değerlendirmeler' olduğu açıktır ve bunlardan sadece birer tanesinin nakledilmesi yeterlidir.

- 986. hadis (Îdeyn, 24) Câbir rivayetidir ve sonunda şu mütâbaat ifadesi vardır: Tâbe'ahû Yûnus b. Muhammed 'an Füleyh. Ve hadîsu Câbir esahhu.

$\mathrm{Bu}$ kısımda çözümü zor bir nüsha ihtilafı vardır. ${ }^{125}$ Çok uzun olan bu meselenin bizi ilgilendiren yönü Zihni Efendi’nin bu kısmı ...'an Füleyh 'an Ebî Hüreyre... şeklinde kaydetmesidir. ${ }^{126}$ Zihni Efendi’nin bu tashihinin yanlış olduğu kesindir; çünkü Füleyh’in Ebû Hüreyre'den rivayette bulunma ihtimali yoktur. Nitekim bu mütâbaatı Ebû Hüreyre rivayeti olarak zikreden nüshalar burayı 'an Füleyh 'an Sa'îd 'an Ebî Hüreyre şeklinde nakletmiştir. ${ }^{127}$

Zihni Efendi'yi yanıltan husus, Kastallânî şerhinde 'an Füleỵ kelimesinden sonra Ebû Zer nüshasından nakilde bulunulmuş olmasıdır. ${ }^{128}$ Zihni Efendi’nin burayı yanlış nakletmesinde Yûnînînin Humeydîden nakilde bulunduğu hamişte burayı 'an Füleyḥ 'an Ebî Hüreyre şeklinde belirtmesinin de rolü olabilir. ${ }^{129}$

- 1372. hadiste (Cenâiz, 86) ne'am 'azâbu'l-kabri hakkun ifadesi geçmektedir. 1373'ün sonunda da zâde Gunder 'azâbu'l-kabri şeklinde bir mütâbaat mevcuttur.

Burada üç tashih olmalıdır: 1. Metin kısmında sadece ne'am 'azâbü'l-kabri ifadesi bulunmalıdır. 2. Bir sonraki hadisin sonunda zikredilen zâde Gunder kısmının asıl yeri bu hadisin, yani 1372'nin sonudur. 3. 1372'den sonra nakledilmesi gereken bu ifadenin sonuna hakkun kelimesi eklenmelidir.

Önce şunu netleştirmek gerekiyor ki, zâde Gunder mütâbaatı 1372'yle ilintilidir. Gunder, yani Muhammed b. Cáfer, Şu'be’nin en meşhur râvisidir ve Şu'be rivayeti, 1372. rivayettir.

124 Bu baskıda Ebû Âsım’dan yapılan ve aynı şeyi ifade eden iki nakil de verilmiştir: Semi'tu Ebâ 'Âsım yezkuru... semi'tu Ebâ Âsım yekûlu... Yine bu baskıda Buhârînin Ubeydullah b. Musảdan yaptı̆̆ı nakil de iki defa çıkmıştır ki, ikincisinin başında, bu nüshayı nakleden İbn Hammûye es-Serahsînnin kimi zaman tekrarladığı Buhârî ve Firebrî isimleri vardır. Hatta burada, Yûnînî nüshasında hiç bulunmayan ve yine Kastallânî şerhini aynen nakletmekten kaynaklandığı anlaşılan üçüncü bir haddesenâ 'Ubeydullâh ifadesi de mevcuttur!

125 Bu ihtilafın ayrıntıları ve Buhârî̉nin burada bir hata yapıp yapmadığı meselesi, yakında neşredilecek çalışmamızda ele alınmaktadır.

126 Çă̆rı, II, 11.

127 İbnü’s-Seken’in (ö. 353/964) nüshası bu şekildedir (İbn Hacer, Fethu’l-Bârî, II, 379).

128 Kastallânî, İrşâd, II, 226. Bu şerhte şöyle geçmektedir: ...('an Füleyh) ve-li-Ebî Zer: 'an Saî̀d ('an Ebî Hüreyre. Ve hadîsu Câbir esahhu). Buradaki parantezler ana metni gösterir ve Ebû Hüreyre ismi yanlışlıkla parantezin içinde zikredilmiştir.

129 Âsitâne, II, 23. Bu yanlışlık Yûnînînin elindeki el-Cem` beyne’s-Sahîhayn nüshasından kaynaklanmıyorsa, Yûnînînin kendisinden kaynaklanmıştır; çünkü matbu halinde böyle bir yanlışlık yoktur (Muhammed b. Futûh el-Humeydî, el-Cem` beyne’s-Sahîhayn [nşr. Ali Hüseyin el-Bevvâb), I-IV, Beyrut: Dâru İbn Hazm, 1998, II, 370; III, 262). 
1373'ün Şu'be’yle de, Gunder'le de alakası yoktur. Nitekim İbn Hacer bazı nüshalarda böyle geçtiğini ama bunun galat olduğunu belirtmektedir. ${ }^{130}$

Elimizdeki metne göre 1372. hadiste "Evet, kabir azabı haktır." denilirken, Gunder rivayetinde sadece "Evet, kabir azabı." ifadesi vardır. Bu durumda Gunder bir şey "eklemiş" değil, eksiltmiş olmaktadır! Hâlbuki durum bunun tamamen tersidir. Çünkü Buhârînin bu mütâbaatı zikretmesinin sebebi, metindeki bu ifadenin eksik gibi durmasıdır ve bu yüzden burayı zâde diyerek nakletmiştir. Nitekim diğer yanlışların kaynağı olan Yûnînînin ana metninde bile hakkun kısmı yoktur. ${ }^{131}$

Bu karışıklık, Sahîh baskılarına ve bazı şerhlere daha da karışık olarak yansımıştır. Mehmed Zihni Efendi metni néam azâbü'l-kabri olarak doğru kaydetmiştir. Fakat zâde Gunder kısmını tamamen kaldırmış, ne yanlış yerde ne de doğru yerde nakletmiştir. ${ }^{132} \mathrm{Bu}$ bir baskı hatası değilse, yanlış bir tashihtir.

- Ammâr b. Yâsir'in şehit edileceğini bildiren meşhur rivayette taktuluhû el-fietüll-bâğiye ifadesi geçmektedir. ${ }^{133}$

Hadisin aslında bu cümlenin olduğu kesindir. Buhârînin bu hadisi zikrettiği iki yerde bu kısmı nakledip nakletmediği ise ihtilaflıdır; çünkü nüshalar arasında farklılık vardır. Nüshaların bir kısmının - büyük bir ihtimalle kendi nüshalarını yazarken yanlışlıkla atladıklarını zannederek - bu cümleyi sonradan ekledikleri, Buhârînin ise çoğu nüshada olduğu gibi aslında bu kısmı nakletmediği İsmailî (ö. 371/982), Berkânî (ö. 425/1034), Ebû Mes'ûd ed-Dımaşkî (ö. 401/1011), Humeydî, Beyhakî (ö. 458/1066), Kadı İyâz (ö. 544/1149), İbnü’l-Esîr (ö. 606/1209-10), Mizzî (ö. 742/1341-42) ve İbn Kesîr (ö. 774/1372-73) gibi önemli muhaddisler tarafından dile getirilmiştir. ${ }^{134}$

Fakat İbn Hacer ilk yerde bunun çoğunluk tarafından nakledilmediğini belirtirken ikinci yerde bir açıklama yapmamış, bunun üzerine Kastallânî bu ikinci yerde Yûnînî metnine uyarak bu cümleyi kaydetmiştir. ${ }^{135}$ Zihni Efendi de Kastallânîye uyarak ilkinde bunu nakletmemiş, ikincisinde nakletmiştir. ${ }^{136}$ Hâlbuki hadisin aslında var olduğu esas alınırsa her iki yerde bunu nakletmek, Buhârînin bunu nakletmediği esas alınırsa her iki yerde nakletmemek daha doğru olsa gerektir.

- 2565. hadisin (Mükâteb, 5) senedi ...haddesenâ 'Abdülvâhid b. Eymen kâle haddesenî ebî Eymen... şeklindedir.

130 İbn Hacer, Fethu'l-Bârî, III, 183.

131 Âsitâne, II, 98.

132 Çă̆rı, II, 102.

133 447: Kitâbü's-salât, Bâbu't-teâvun... (63); 2812: Kitâbü'l-cihâd ve's-siyer, Bâbu meshi'l-gubâr... (17).

$134 \mathrm{Bu}$ isimlerin bir kısmı için bk. İbn Hacer, Fethu'l-Bârî, I, 430.

135 İbn Hacer, Fethu'l-Bârî, I, 430; Kastallânî, İrşâd, I, 442, V, 49.

136 Çağrı, I, 115, III, 207. 
Zihni Efendi herhalde bu ismin Ebû Eymen olduğunu zannederek haddesenî lafzından sonra Ebûşeklindegelmesi gerektiğini düşünmüş ve burayı Ebû Eymen olarakkaydetmiştir. ${ }^{137}$ Hâlbuki Abdülvâhid burada "babam Eymen" demektedir. Nitekim Yûnînî nüshasında haddesenî ebî Eymenu olarak kayıtlıdır ${ }^{138}$ ve bu nüshayı esas alan Sahîh baskılarında da böyle geçer. ${ }^{139}$ Zihni Efendi’nin burayı tashih ederken Aynîye bakmadığı anlaşılmaktadır. Çünkü bu şerhte isimlerin izahı mevcuttur. ${ }^{140}$

- 2842. hadiste (Cihâd, 37) dünya malının aldatıcı oluşuyla ilgili bir temsil anlatılırken

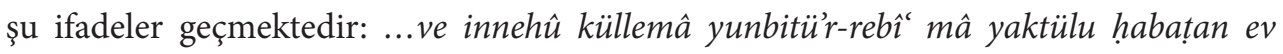
yulimmu, küllemâ ekelet hattâ...

$\mathrm{Bu}$ ifadede düzeltilmesi gereken birkaç yer olmasına rağmen ${ }^{141}$ Zihni Efendi kenarda Kastallânîden nüsha farklılıklarına dair bilgiler nakletmekle yetinmiş, sadece illâ âkilete’lhaḍr ifadesini eklemiştir. ${ }^{142}$ Çünkü Yûnînî nüshasında ikinci küllemâ ifadesinin üzerine şüphe bildiren tadbîb işareti konulmuş, kenara da şu not eklenmiştir: savâbuhû illâ âkilete’lhaḍır ekelet. ${ }^{143}$ Fakat Zihni Efendi büyük bir ihtimalle şerhteki notların karışıklığından kaynaklanan bir hatayla bu ifadeyi küllemâ kelimesini kaldırmadan ve ekelet kelimesinden sonra nakletmiş, böylece anlam olarak zaten sorunlu olan bir metni tamamen içinden çıkılamaz bir hale getirmiştir: ...ev yulimmu, küllemâ ekelet illâ âkilete'l-haḍr hattâ...

- 4129. hadis (Megâzî, 31) şu şekilde başlamaktadır: 'an men şehide Rasûlellâhi yevme zâti'r-rıkâ' sallâ salâte'l-havf...

Mehmed Zihni Efendi burayı 'an men şehide me'a Rasûlillâhi yevme zâti'r-rıkâ' sallâ salâte’l-ḩavf şeklinde kaydetmiştir. ${ }^{144}$ Zihni Efendi’nin tashihi Kastallânî şerhinde bulunan metne dayanmaktadır. ${ }^{145}$ Fakat burada bir hata olduğu açıktır; çünkü bu şerhin temel aldığ1 Yûnînî nüshasında me`a kelimesi bulunmaz. ${ }^{146}$ Zaten Kastallânî de bu kısımla ilgili hiçbir izahta bulunmamıştır. Ayrıca bu haliyle cümlede bir ifade düşüklüğü mevcuttur; çünkü "Hz. Peygamber'le beraber şahit oldu, korku namazı kıldı" gibi bir anlama gelmektedir.

- 4904. rivayet olan Zeyd b. Erkam hadisinde (Tefsîr, Münâfikûn suresi, 4) bir cümle atlanmış, metinde bir anlam bozukluğu oluşmuştur. Ebû Zer ve Semânî nüshalarında

137 Çağrı, III, 128. Bu bir baskı hatası değildir; çünkü harekeleme (Ebû Eymene) buna göre değiştirilmiştir.

138 Âsitâne, III, 153.

139 Mesela bk. Sahîhu'l-Buhârî, Dâru'l-Erkam, nr. 2565.

140 Aynî, Umde, XI, 23. Kastallânî̀de ise ebî Eymen olarak geçmekte ama buna dair herhangi bir açılama yapılmamaktadır (bk. İrşâd, IV, 333).

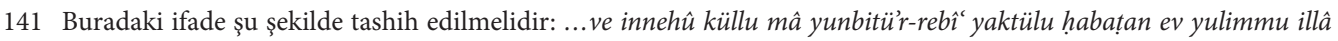
âkilete'l-ḥậdr; ekelet hattâ...

142 Çağrı, III, 214.

143 Âsitâne, IV, 27.

144 Çă̆rı, V, 52.

145 Kastallânî, İşâd, VI, 333.

146 Âsitâne, V, 114 Ezherli âlimler ellerindeki hiçbir nüshada méa kelimesinin bulunmadığını belirtmektedirler. 
mevcut olan bu kısım aşağıda altı çizili olarak gösterilmiştir: ...fezekertu zâlike líammî fezekera 'ammî lin-Nebî fe-de'ânî fe-haddestuhû fe-ersele ilâ 'Abdillâh b. Übey ve ashâbihî̀ fe-hâlefû mâ kâlû ve kezzebenin-Nebî̀ ve saddekahum... ${ }^{147}$

Zihni Efendi metinden düşen bu kısmı eklemiş ama bu eklemeyi saddekahum ifadesinden sonra yapmış ve böylece başka bir anlam düşüklüğüne sebep olmuştur. ${ }^{148}$ Onu yanıltan şey, tashihindeki kaynak olan Kastallânîdeki şu durumdur: Bu şerhte önce Yûnînînin ana metnindeki fe-zekerahî 'ammî lìn-Nebî ve saddekahum cümlesi kaydedilmiş, sonrasında Ebü'l-Vakt ve Ebû Zer nüshalarında şu şekildedir denilerek atlanan kısım zikredilmiş, fakat bunun ve saddekahum ifadesinden önce olduğu belirtilmemiştir. ${ }^{149}$

\subsubsection{Gözden Kaçırdığı Bariz Örnekler}

Bugünkü imkânların olmadığı bir ortamda bir hadis kitabını, hem de Buhârî gibi bir hadis kitabını tashih etmek kolay bir şey değildir. Dolayısıyla bu tashihi bir kişiden beklemek haksızlık olacaktır. Bizim burada Zihni Efendi’nin gözden kaçırdığı yerlerden örnekler aktarmamızın sebebi, tashih işleminin devam etmesinin ve geliştirilmesinin gerekliliğine vurgu yapmaktır. Çünkü kişilerin ilmi sınırlıdır ve hiçbir kimse yanlış yapmaktan beri değildir. Mehmed Zihni Efendi’nin bu işi başlatmasının bile çok önemli bir adım olduğunu daha önce dile getirmiştik.

Bu kısımda kaydedeceğimiz örnekler hata oldukları açık olan yerlerden seçilmiştir. Zihni Efendi’nin buralarda tashih yapmaması Kastallânî şerhinin bu kısımlarda zayıf kalmasından kaynaklanmıştır ki, izahı kısa olanlara burada temas edilecektir.

- Metni bulunmayan 221'inci rivayetten sonra 58. bâb başlğ̆1 (Bâbu yuhâriku'l-mâe 'ale'lbevli) gelmekte ve arkasından numarasız bir hadis başlamaktadır: Haddesenâ Hâlid... ${ }^{150}$

Buradaki hata şudur: Diğer nüshalarda hiç olmayan bu başlık tamamen yanlış yere, yani iki senedi olan bir hadisin bu iki senedinin arasına konmuştur. Buna göre buradaki bâb başlığ 1 kesinlikle kaldırılmalı, numarasız rivayet ise 221'in ikinci senedi ve metni olarak zikredilmelidir.

İbn Hacer'in bu bâb başlı̆̆ından haberi yoktur; o sadece, iki senedin de bu hadisle alakalı olduğunu bildiğinden metnin hangi senede ait olduğu hususuna değinmektedir. ${ }^{151}$ Aynînin metninde 've haddesenâ Hâlid' ifadesinden önce tahvîl $(\mathrm{H})$ işareti bile mevcuttur; yani öncekinin birinci, bunun ise ikinci sened olduğu çok açıktır. ${ }^{152}$ Yûnînîde bu bâb başlığ 1

147 Âsitâne, VI, 153.

148 Çă̆rı, VI, 65.

149 Kastallânî, İrşâd, VII, 387 Kastallânî, Semânî nüshasına 'Ebü’l-Vakt nüshası' demektedir; bu tamamen yanlış olmasa da eksik bir nitelemedir ve Yûnînînin buna dair izahına uymamaktadır.

150 Kitâbü'l-vudû', 58; Çağrı, I, 61-2.

151 İbn Hacer, Fethu'l-Bârî, I, 258-9.

152 Aynî, Umde, II, 446-7. 
vardır ve yanlışlık buradan, yani onun esas aldığı nüshadan kaynaklanmaktadır. Kenarda ise İbn Asâkir, Ebû Zer ve Asîlî nüshalarında bu bâbın bulunmadığı belirtilmekte, hatta İbn Asâkir ve Asîlîde - İbn Hacere göre Kerîme dişındaki bütün nüshalarda - ikinci sened olduğunu gösteren ve (ve haddesenâ Hâlid) lafzı bulunmaktadır. ${ }^{153}$

- 1658.hadisinsenedişuşekildedir:...HaddesenâSüfyân, 'ani’z-Zührî,haddesenâSâlim... ${ }^{154}$

Bu isnâdda Zührî ismi olmamalıdır. Doğrusu ...Haddesenâ Süfyân, haddesenâ Sâlim şeklindedir. Buradaki Sâlim, Zührînin (ö.124/742) çokça rivayette bulunduğu Sâlim b. Abdullah b. Ömer (ö. 106/725) değil; Ebü’n-Nadr olarak meşhur olan Sâlim'dir (ö. 129/187). Ondan rivayeti olanlar da Zührînin talebeleri olan Süfyan b. Uyeyne, Mâlik b. Enes, Abdülaziz b. Ebî Seleme gibi isimlerdir. Bazı nüshaların araya Zührî ismini koyarak hatalı tashih yapmalarının sebebi, bu Salimleri karıştırmaları ve Zührî isminin yanlışlıkla düştüğünü zannetmeleridir.

Nitekim bu hadisin bir tekrarı olan 5604. rivayette Süfyan isminden sonra Sâlim gelmektedir; Zührî ismi yoktur. ${ }^{155} 5604$ 'te Zührî ismi yanlışlıkla atlanmış da değildir; çünkü bu rivayeti Buhârîye nakleden Humeydînin (ö. 219/834) kendi kitabında da sened bu şekildedir. ${ }^{156}$ Süfyan’n diğer râvileri olan Ahmed b. Hanbel, ${ }^{157}$ İshak b. İbrahim ve İbn Ebî Ömer'in ${ }^{158}$ rivayetlerinde de Zührî ismi bulunmaz. Yûnînî her ne kadar nüsha farklılığına değinmese de Basrînin Kastallânîden naklettiği açıklamada "bazı sahih asıllarda Zührî kaydının bulunmadığı" belirtilmektedir. ${ }^{159}$

Mizzî (ö. 742/1341-42), Buhârîdeki bu rivayeti “Süfyan’n Sâlim’den rivayeti” şeklinde nakletmiş, İbn Hacer de buna düştüğü dipnotta "bazı nüshalarda Zührî isminin bulunduğunu ve bunun yanliş olduğunu, doğrusunun Eşribe’de (5604) geçtiğini” söylemiştir. ${ }^{160}$

- 2637. hadiste iki sened vardır. İlk sened Abdullah b. Ömer en-Nümeyrîdden sonra gelen Sevbân ismiyle bittikten sonra ikinci sened ve kâle'l-Leys şeklinde, yani muallak olarak başlamaktadır. ${ }^{161}$

Burada Sevbân isminin olması yanlıştır; çünkü Sevbân isminde bir râvi yoktur. ${ }^{162}$ Bunun yerine, ikinci senedde de ismi geçen Yunus yazılmalıdır. Nitekim diğer bütün nüshalarda Sevbân yerine Yunus ismi vardır. ${ }^{163}$

153 Âsitâne, I, 54.

154 Kitâbü'l-hac (25), Bâbu savmi yevmi 'arafe (85); Çağrı, II, 173.

155 Kitâbü'l-eşribe (74), Bâbu şurbi'l-leben (12), 2. hadis; Çağrı, VI, 245.

156 Abdullah b. ez-Zübeyr el-Humeydî, el-Müsned (nşr. Hüseyin Selim Esed), Dımaşk: Dâru’s-Seka, 1966, I, 334 (341).

157 Ahmed b. Hanbel, el-Müsned, I-VI, İstanbul: Çağrı Yayınları, 1992, VI, 339.

158 Müslim b. el-Haccâc, Sahîh, I-III, İstanbul: Çağrı Yayınları, 1992, Savm 110.

159 Âsitâne, II, 161. Kastallânî, Zührî isminin sadece Yûnînînin kopyasında geçtiğini söyler (İrşâd, III, 196).

160 Mizzî, Tuhfetü'l-eşrâf, 18054. hadis.

161 Kitâbü’ş-şehâdât (52), Bâbu izâ 'addele raculun... (2), ilk hadis; Çağrı, III, 146; İbn Hacer, Fethu'l-Bârî, V, 190.

162 Kütüb-i Sitte ricâli içerisinde Sevbân isminde sadece Hz. Peygamber'in azatlısı Sevbân (ö. 54/674) bulunur (bk. İbn Hacer, Takrîbü’t-Tehzîb [nşr. Muhammed Avvâme], Medîne: Dâru’l-Yüsr, 2012, s. 174).

163 Yûnînî nüshasında "Yunus isminin sadece Ebû Zer nüshasında geçtiğinin" belirtilmesi (Âsitâne, III, 168) gerçekten 
$\mathrm{Bu}$ rivayetin tekrarlandığı bir yerde ${ }^{164}$ burada geçen Abdullah en-Nümeyrî̀den sonra haddesenâ Yunus ifadesi geçmektedir ki, bu meseleyi netleştirmektedir. Kastallânîburadaki Sevbân ismini metinde nakletmiş, bununla ilgili ihtilaftan ve Ebû Zer nüshasından bahsetmiş ancak İbn Hacer’in şerhinde bu isimle ilgili bir yorum mevcut olmadığından herhangi bir değerlendirmede bulunmamıştır. ${ }^{165}$ Buna binaen Mehmed Zihni de herhangi bir tashih yapmamıştır.

- 3485. hadisin senedinde "haddesenâ Bişr b. Muhammed, ahberenâ 'Ubeydullah..." ibaresi vardir. 166

Buradaki Ubeydullah ismi Abdullah olarak tashih edilmelidir. Zira Bişr b. Muhammed (ö. 224/839), Abdullah b. Mübârek'in (ö. 181/797-98) râvilerindendir ve Sahîh'teki diğer 21 rivayeti de ondandır. İbn Hacer ve Aynî, her ne kadar şerhlerine sonradan eklenen metinlerde Ubeydullah ismi geçse de 'Abdullah huve İbnu'l-Mübârek açıklamasını yapmışlardır. ${ }^{167}$ Kastallânînin naklettiğine göre Yûnînîde Ubeydullah ismi olmakla beraber bir kopyasında düzeltme işareti vardır. ${ }^{168}$

- 3946. hadisin senedinde tahvil işareti $(\mathrm{H})$ bulunmaktadır: ... haddesenâ Mu'temir kâle ebî $(\mathrm{H})$ ve haddesenâ Ebû Osman... 169

$\mathrm{Bu}$ tahvil işareti kesinlikle kaldırılmalıdır. Çünkü burada yanlış bir bilgiye sebep olmaktadır. Bu işaret bir senedden başka bir senede, bazen de bir şeyhten başka bir şeyhe geçildiğini belirtmek için konulur. Mesela buradaki işaret Mu'temir'in (ö. 187/803) hem babası Süleyman b. Tarhan (ö. 143/760-61) hem de Ebû Osman en-Nehdî̀den (ö. 100/719) dinlediğini anlatmaktadır ki, bu mümkün değildir. Çünkü Mu'temir, Ebû Osman'ın vefat ettiği sene doğmuştur. Ebû Osman'dan rivayette bulunan sadece Süleyman b. Tarhan'dır.

Aslında Yûnînî nüshasında bu işaret yoktur. ${ }^{170}$ Mehmed Zihni de dâhil bu işaretin eklendiği baskıları yapanları şaşırtan ve sanki iki kişiden birden nakledildiğini düşündürten $\underline{v e}$ haddesenâ... ifadesinin, yani başındaki atıf harfinin açıklaması ise şöyledir: Bu hadis, Süleyman’ın Ebû Osman'dan naklettiği bir grup hadis içerisinden alınmıştır ve alındığ nüshada da ifade bu şekildedir. Nitekim bunun bir nüsha olduğu veya bir grup hadisi birden naklettiği hususu, diğer bazı rivayetlerde daha belirgindir. Mesela 5382. rivayette şöyle geçer: ...haddesenâ Mu'temir [b. Süleyman] 'an ebîhi kâle ve haddese Ebû̀ Usmân eydan 'an... ${ }^{171}$

gariptir.

164 6662: Eymân, 13 (Çağrı, VII, 225).

165 Kastallânî, İrşâd, IV, 372.

166 Kitâbu ehâdîsi'l-enbiyâ (60), son bâb, sondan 3. hadis; Çağrı, IV, 152; Âsitâne, IV, 177.

167 İbn Hacer, Fethu'l-Bârî, VI, 408 (eklenilen yanlış metinden etkilenerek şerhteki isim de Ubeydullah yapılmıştır); Aynî, Umde, XIII, 120.

168 Kastallânî, İrşâd, V, 442.

169 Menâkıbü'l-Ensâr (63), İslâmu Selmân el-Fârisî (53); Çağrı, IV, 270; İbn Hacer, Fethu’l-Bârî, VII, 222; Sehârenfûrî, VII, 790.

170 Âsitâne, V, 71.

171 Kitâbü’l-et'ime (70), Bâbu men ekele hattâ şebía (6), 2. hadis; Çağrı, VI, 198. 
- 6900'üncü rivayetin senedi şöyle başlamaktadır: Haddesenâ Ebü’l-Yemân, haddesena Hammâd b. Zeyd... ${ }^{172}$

Buhârînin bu hadisteki şeyhi Ebü'l-Yemân değil, Ebü’n-Nu'mân'dır; bu şekilde düzeltilmelidir. Yûnînînin ana metninde Ebü’l-Yemân olan bu isim kenarda belirtildiğine göre Ebû Zer, Asîlî, İbn Asâkir ve Semânî nüshalarında Ebü’n-Nu'mân şeklindedir. ${ }^{173}$ Sagânî nüshasında ve Sehârenfûrîde de Ebü’n-Nu'mân ismi geçer. ${ }^{174}$ Burada ismi geçen Ebü'lYemân Hakem b. Nâfi', Buhârînnin en çok rivayette bulunduğu şeyhlerindendir ancak onun Sahîh'teki tüm rivayetleri Şu'ayb b. Ebî Hamza’dandır. Ebü’n-Nưmân Muhammed b. elFadl ise söz konusu rivayette adı geçen Hammâd b. Zeyd'den en çok rivayette bulunanların başında gelir.

\section{Sonuç}

Bir kitabın tashih edilmesi, o kitaba yapılan hizmetin bir parçasıdır ve bir kitabın önemi arttıkça o kitaba yapılan hizmet de artar. Sahîh-i Buhârî̀ye yapılan hizmet herkesin malumu olmakla beraber bunun ayrıntıları kimi zaman gizli kalmaktadır. Zihni Efendi’nin Sahîh-i Buhârî tashihi işte bu pek bilinmeyen hizmetlerden bir tanesidir.

Osmanlının son devrinin önemli simalarından olan Mehmed Zihni Efendi âlim kişiliğinden daha çok müderris ve yenilikçi kimliğiyle öne çıkmaktadır. Nimet-i İslâm ve Meşâhîr-i Nisâ gibi yeni tarz eserler yanında, Arapça öğretiminin Türkçe yapılması ile daha kolaylaşacağını düşünerek Müntehab ve Muktedab kitaplarını yazması ve devrin önemli okullarında bunu başarıyla uygulaması onun bu yenilikçi yönünü gösterir. İstanbul'da Sahîh $i$ Buhârî̀yi basan ilk kişi oluşu ve bu baskıda günümüzde bile yapılamayan tashihler yapması onun bu yönünün bir parçası olmalıdır.

Zihni Efendi'ye bu tashih işleminde cesaret veren diğer bir husus, Mısır'daki baskıda musahhihlerin bazı tashihlerde bulunmasıdır. Nitekim kitabın sonunda Zihni Efendi onlara teşekkür etmektedir. Bu baskıda Yûnînî nüshası kullanıldığından tashih için Kastallânînin (ö. 923/1517) şerhinin seçilmesi önemlidir. Çünkü Yûnînî nüshasının esas alındığı bu şerhte İbn Hacer’in açıklamaları bir miktar dikkate alınmış ve nüshadaki bazı yanlışlara dikkat çekilmiştir. Nitekim Kastallânî Sahîh-i Buhârî metni olarak kimi zaman Yûnînînin ana metninde yazılanı nakletmemiş, bunun yerine Ebû Zer nüshasındaki ibareyi tercih etmiştir. Zihni Efendi, Kastallânî şerhi yanında Aynînin (ö. 855/1451) şerhini de dikkate almış ve bazı tashihlerini buradaki izahlara dayandırmıştır.

Verdiğimiz örneklerde görüldüğü gibi Mehmed Zihni bu tashihlerinde genellikle isabetli olmuştur. Bununla beraber bazı eksik ve yanlış tashihleri de vardır. Bu yanlış tashihler

172 Kitâbü’d-diyât (87), Bâbu men ittalaáa fî beyti kavmin... (23), 1. hadis; Çağrı, VIII, 44.

173 Âsitâne, IX, 10.

174 Sehârenfûrî, XIII, 434. 
kanaatimizce Kastallânînin yanlış tercihlerinden ve kimi zaman da Zihni Efendỉnin Yûnînî nüshasındaki bütün haşiyeleri metne yansıtmak istemesinden kaynaklanmıştır.

$\mathrm{Bu}$ tashihte gözden kaçırılan yerlerin varlığı kaçınılmazdır. Çünkü hacimli bir hadis kitabının, hem de Sahîh-i Buhârî gibi tertip ve tasnifinde incelikler bulunan bir kitabın tashih edilmesi ciddi zorlukları bünyesinde barındırır. Bu çalışma gözden kaçırılan yerlerden bazı örnekleri sunarak Zihni Efendi’nin bu tashihlerinin devamının gelmesi gerektiğine dikkat çekmeyi hedeflemektedir. Ayrıca tashih faaliyeti bir ekiple yürütülmeli ve temel eserlerin tashihi aşamalı ve devamlı olmalıdır.

Zihni Efendi’nin tashihlerinin bilinmemesi, sonraki baskılarda bu düzeltmelerin yapılmamasına sebep olduğu gibi tashih işleminin birbirine eklenerek gelişmesine de engel olmaktadır. Son dönemde Yûnînî nüshasının/Bulak baskısının tıpkıbasımı çokça yapılmasına rağmen bu çalışmada söz konusu edilen ve edilmeyen hataların aynen devam etmesinin açıklaması da budur. Çünkü hadis kitaplarının aynen nakledilmesi esastır, bunların tashih edilmesi ayrı bir çalışmayı gerekli kılmaktadır.

Aslında İbn Hacer'in şerhi, Sahîh'in tashihi için muazzam bir kaynak konumundadır. Fakat buradaki bilgilerin tashihe bir türlü yansıyamadığı bir gerçektir. Çünkü bu bile bir emek gerektirmekte ve her şeyden önce böyle bir tashihin lüzumuna inanılması gerekmektedir.

Çalışmada da görüldüğü üzere Zihni Efendi’nin tashihlerinin bir kısmı mütâbaât, bir kısmı kelimenin okunuşları, önemli bir kısmı da seneddeki hatalarla ilgilidir. Geneli hadisin sıhhatini ve anlamını zedeleyen bir mahiyet arz etmese de bu hatalar bugün neşredilen ve daha çok Bulak baskısını esas alan Sahîh-i Buhârî metin ve şerhlerinde mevcuttur. Bu sebeple Mehmed Zihni’nin tashihleri günümüz için de önem arz eder. Bizim değerlendirmemize göre Sahîh metninde yeni tashihler yapılana kadar onun neşrinin tercih edilmesi ancak bu çalışmada dile getirilen hata ve eksikliklerin düzeltilerek bu neşrin yapılması gerekmektedir. 


\section{Kaynaklar}

Ahmed b. Hanbel, el-Müsned, I-VI, İstanbul: Çağrı Yayınları, 1992.

Aydın, Arafat - Ali Albayrak. "Sahîh-i Buhârî Nüshalarına Dair Yeni Bulgular: Bulak Baskısı, Yûnînî Yazmaları ve Abdullah b. Sâlim el-Basrî Nüshası.” İslâm Araştırmaları Dergisi, 2016, sy. 35, s. 1-39.

Aydın, Arafat. Sagânînin Sahîh-i Buhârî Nüshası ve Türkiye Kütüphanelerindeki Yazmaları (uzmanlık tezi, 2016), İstanbul: Türkiye Yazma Eser Kurumu Başkanlığı.

Aydınl, Abdullah. "Asıl (Hadis)." DİA, III, 473.

el-Aynî, Bedreddîn Mahmud b. Ahmed. Umdetül-kârî fî şerhi Sahîhi'l-Buhârî. I-XX, Mısır: Mektebetü Mustafa el-Bâbî, 1972.

el-Basrî, Abdullah b. Sâlim. Dıyâü's-sârî fî mesâliki ebvâbi Sahîhi'l-Buhârî (nşr. Nûreddîn Tâlib). I-XVIII, Katar: Dâru’r-Rakîm, 2011.

------. Yunînî nüshası (Basrî kopyası). Konya Yusuf Ağa Yazma Eser Kütüphanesi, nr. 5555.

el-Buhârî, Muhammed b. İsmail. Sahîhu’l-Buhârî (Mısır/Bulak neşrinin tıpkıbasımı). I-IX, Üsküdar: Âsitâne Kitabevi, 2003.

-----. Sahîhu'l-Buhârî (Mehmed Zihni neşrinin tıpkıbasımı). I-VIII, İstanbul: Çağrı Yayınları, 1992.

----.-Sahîhu'l-Buhârî. Beyrut: Dâru’l-Erkam, ts.

el-Ceyyânî, Ebû Ali el-Gassânî. Kitâbü't-Tenbîh ale'l-evhâmi'l-vâkı'a fi's-Sahîhayn min kıbeli'r-ruvât, Kısmu'lBuhârî (nşr. Mehmed Sâdık Aydın). Riyad: Dâru'l-Livầ, 1987.

Cuma Fethî Abdülhalîm. Rivâyâtü’l-Câmi'i's-sahîh ve nüsehuhû. Mısır/Katar: Dâru'l-Felâh, 2013.

Ermiş, Hamza. Mehmed Zihni Efendi - Hayatı, Eserleri ve Arapça Öğretimindeki Yeri. İstanbul: İSAM, 2011. el-Humeydî, Muhammed b. Futûh. el-Cem‘ beyne’s-Sahîhayn (nşr. Ali Hüseyin el-Bevvâb). I-IV, Beyrut: Dâru İbn Hazm, 1998.

el-Humeydî, Abdullah b. ez-Zübeyr. el-Müsned (nşr. Hüseyin Selim Esed). Dımaşk: Dâru’s-Sekâ, 1966.

İbn Hacer, Ahmed b. Ali b. Muhammed el-Askalânî. Fethu'l-Bârî şerhu Sahîhi'l-Buhârî. I-XIII, Beyrut: Dâru İhyâi't-Türâsi'l-Arabî, 1982.

----.-. Takrîbü’t-Tehzîb (nşr. Muhammed Avvâme). Medîne: Dâru'l-Yüsr, 2012.

İbnü'l-Mebrid, Yusuf b. el-Hasan, el-İhtilâf beyne ruvâti'l-Buhârî ani'l-Firebrî ve rivâyât an İbrahim b. Ma‘kıl en-Nesefî (nşr. Salâh Fethî Helel), Riyad: Dâru'l-Vatan, 1999.

İşler, Emrullah. “Tashîf." DİA, XL, 128.

Kadı İyâz b. Musa. Meşâriku'l-envâr alâ sıhâhi'l-âsâr (nşr. Ahmed Sâlih eş-Şâmî). I-III, Dımaşk: Dâru'lKalem, 2012.

el-Kastallânî, Ahmed b. Muhammed. İrşâdü’s-sârî li-şerhi Sahîhi'l-Buhârî. I-X, Beyrut: Dâru İhyâi't-Türâsi'lArabî, ts.

el-Mizzî, Yusuf b. Abdurrahman. Tuhfetü’l-eşrâf bi-ma'rifeti'l-etrâf me'a en-Nüketi'z-zırâf li’bn Hacer (nşr. Şeyh Abdürrezzâk el-Mehdî). I-XII, Beyrut: Dâru'l-Kitâbi'l-Arabî, 2008.

Müslim b. el-Haccâc, Sahîh, I-III, İstanbul: Çağrı Yayınları, 1992.

Özsöy, Abdulvahap. Buhârî Nüshaları ve Nüsha Farklılıklarının Mahiyeti Üzerine. Kayseri: Fenomen Yayıncllık, 2016.

Özşenel, Mehmet. “Sahîh-i Buhârî Neşirleri: Sehârenpûrî Neşri ile II. Abdülhamid Neşrinin Karşılaştırılması.” Türkiye Araştırmaları Literatür Dergisi, 2013, XI, sy. 21, s. 454-484.

es-Sagânî, Radıyyüddin Hasan b. Muhammed. Sahîh-i Buhârî nüshası. Süleymaniye Yazma Eser Kütüphanesi, Damad İbrahim, nr. 266-269.

es-Sehârenfûrî, Ahmed Ali. el-Câmi'u's-sahîh bi-hâşiyeti'l-muhaddis es-Sehârenfûrî (nşr. Takıyyüddin enNedvî). I-XV, Beyrut: Dâru'l-Beşâiri'l-İslâmiyye, 2011. 